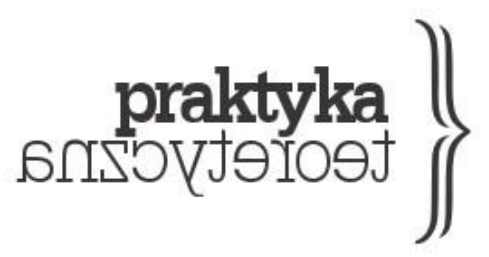

\title{
JAKĄ TEORIĄ JEST MARKSOWSKA TEORIA WARTOŚCI OPARTEJ NA PRACY?
}

\author{
KRZYSZTOF NOWAK-POSADZY
}

\begin{abstract}
Abstrakt: Tak zwana teoria wartości opartej na pracy (odtąd LTV), niegdyś powód do dumy całego środowiska marksistowskiego, stawała się $\mathrm{z}$ upływem lat przedmiotem jego zakłopotania. Jej odrzucenie w ramach tradycji lewicowej, zarówno przez część filozofów, jak i ekonomistów, wpisuje się w szersze zjawisko zwane „kryzysem marksizmu”. Wówczas to filozoficzna część środowiska marksistowskiego, chcąc uwolnić marksizm od wad „ekonomizmu”, odcięła go także od zalet mogących płynąć z przyjęcia perspektywy ekonomii teoretycznej. Natomiast część ekonomiczna przywołanego środowiska, chcąc uwolnić ekonomię marksistowską od niedociągnięć tkwiących w LTV, odcięła ją także od szczególnego statusu przypisywanego w tej tradycji intelektualnej pojęciu pracy. Chociaż uniewinniono później LTV od zarzutu o domniemaną logiczną sprzeczność, to jedynie po to, aby skazać ja następnie na zapomnienie za jej rzekomą zbyteczność. W niniejszym artykule omówiona zostanie specyfika Marksowskiej wersji LTV. We wstępie podane zostaną cztery jakościowe założenia, które, zdaniem autora, przesądzaja o charakterze Marksowskiej wersji LTV, W pierwszej części zarysowane zostanie miejsce LTV w historii myśli ekonomicznej. Druga część dotyczyć będzie losów Marksowskiej wersji LTV w ramach samej tradycji marksistowskiej. W trzeciej części omówiony zostanie problem wartości i jej pomiaru. Czwarta część zostanie poświęcona analizie problemu pracy i wyboru jednostki jej pomiaru, a także próbie zrekonstruowania Marksowskiej teorii reprodukcji pracowników za pomoca pracy. W części piątej podjęta zostanie kwestia tego, jak interpretuje się współcześnie status metodologiczny marksowskiej wersji LTV. Artykuł kończy podsumowanie.
\end{abstract}

Słowa kluczowe: Marks, teoria wartości opartej na pracy, wartość, ekonomia polityczna, ekonomia marksistowska, miara, praca. 


\section{Wstęp}

W niniejszym artykule zakres omawianych koncepcji teoretycznych składających się na gmach myśli marksowskiej ogranicza się do tzw. teorii wartości opartej na pracy (dalej: LTV), a zwłaszcza na jej ekonomicznej interpretacji. Autor nie zamierza jednak szczegółowo zrelacjonować skomplikowanych losów ani wykładać wszelkich technicznych niuansów omawianej koncepcji1. W zamian - oprócz zrekonstruowania istotnych założeń leżących u podstaw marksowskiej wersji LTV - proponuje się z jednej strony, by zaprezentować wybrane zarzuty pochodzące z innych szkół ekonomii heterodoksyjnej, w których wskazywano na mocne i słabe strony marksowskiej wersji LTV, z drugiej zaś, by spojrzeć na marksowską wersję LTV przez pryzmat trzech fundamentalnych elementów: pojęcia wartości, pojęcia pracy oraz metody dociekań. Autor zdaje sobie sprawę, że niejednokrotnie już podnoszono problem LTV w zbliżony sposób, ale ma nadzieję, że poniższe analizy rzucą nieco nowego światła na sposób interpretacji omawianej koncepcji.

W niniejszym artykule wnosić się będzie o specyfice marksowskiej wersji LTV na podstawie czterech podstawowych założeń:

(i) w ramach LTV opisuje się nie tyle techniczne stosunki pomiędzy rzeczami (towarami), fizyczne relacje efektywności między nakładami a wynikami, czy też ilościowe relacje między cenami, ile horyzontalne i wertykalne społeczne stosunki pomiędzy osobami (stosunki produkcji towarów i reprodukcji stosunków społecznych);

(ii) praca to $\mathrm{w}$ pierwszym przybliżeniu praktyka społeczna (społeczny stosunek produkcji), wywodząca się z idei pracy abstrakcyjnej, której nie można zredukować - nie tracąc przy tym istotnych informacji - ani do innych towarów konsumpcyjnych w formie środków utrzymania, ani do nakładu produkcyjnego $\mathrm{w}$ formie technicznego czynnika produkcji, rozumianego przez pryzmat idei przykrości wysiłku;

(iii) siła robocza to szczególny przedmiot wymiany niebędący towarem, a stanowiący raczej potencjalną zdolność do pracy, której produkcja i reprodukcja nie jest w całości ani zorganizowana, ani kontrolowana zgodnie z logiką systemu kapitalistycznego; mimo że siła robocza jest przedmiotem wymiany na quasi-konkurencyjnym rynku i obiektem rozporządzania wewnątrz przedsiębiorstwa, opisując kształtowanie się wartości siły roboczej (zdolności do pracy) i jej relacji do ceny siły roboczej (płacy) oraz alokacji siły roboczej przez rynek $\mathrm{i}$ wewnątrz przedsiębiorstwa, ekonomia teoretyczna powinna $-z$ uwagi na kilka osobliwości pracy i siły roboczej (np. niekompletność umów o pracę) - różnić się jakościowo od teorii dotyczących kształtowania się wartości i cen innych towarów;

1 W celu zapoznania się z charakterystyką LTV w jej klasycznej wersji zob. Meek (1958). Nowe rozwinięcia $\mathrm{i}$ interpretacje omawianej koncepcji, zob. Foley (2000). 
(iv) wartość wyrażona $\mathrm{w}$ jednostkach pracy to społecznie niezbędny czas pracy abstrakcyjnej, który - ucieleśniony w zwykłych towarach - stanowi podstawę marksowskiej teorii wartości dodatkowej (wyzysku) i akumulacji².

W związku z powyższym struktura artykułu prezentuje się następująco: w pierwszej części zostanie przedstawione miejsce LTV w historii myśli ekonomicznej; druga część będzie dotyczyć losów marksowskiej wersji LTV w myśli marksistowskiej i heterodoksyjnej; w trzeciej części zostanie omówiony problem wartości i jej pomiaru; czwarta część będzie poświęcona analizie problemu pracy i jej pomiaru oraz przybliżeniu marksowskiej teorii reprodukcji pracowników za pomoca pracy; w części piątej zostanie podjęta kwestia tego, jak czy marksowska propozycja jest w ogóle teorią (wartości) w uznawanym obecnie w ekonomii tego słowa znaczeniu; artykuł zakończony jest podsumowaniem.

\section{Problem teorii wartości opartej na pracy w myśli ekonomicznej}

LTV stanowi jedną z najbardziej intrygujących zagadek w historii myśli ekonomicznej. Począwszy od Locke’a, przez Petty'ego, Quesnaya, Smitha, Ricarda, Milla, a skończywszy na Marksie stanowiła ona nieprzerwanie rdzeń rodzącej się i dojrzewającej ekonomii politycznej. Odwrót od tej teorii rozpoczął się około 1870 roku, kiedy wraz z rewolucją marginalistycznosubiektywistyczna przeważająca część środowiska ekonomicznego postanowiła porzucić jej ramy teoretyczne na rzecz ram wyznaczonych koncepcjami popytu i podaży oraz użyteczności i produkcyjności krańcowej. Taki obrót spraw może wydawać się tym bardziej interesujący, gdy się pamięta, że choć klasycy ekonomii politycznej nie znali w pełni analizy marginalnej, to byli doskonale świadomi walorów i słabości rozumowania za pomoca kategorii popytu i podaży, wartości użytkowej (użyteczności całkowitej) i wydajności (produktywności). Co więcej, często nawet z niego korzystali, a mimo to - lub właśnie z tego powodu - szukali fundamentów ekonomii politycznej głębiej, podciagając rozumowanie w kategoriach popytu i podaży pod ogólniejszą teorię wartości opartej na pracy.

Przypomnijmy, że wśród komentarzy do marksowskiej wersji LTV najczęściej pojawiały się zarzuty, że narusza ona zasadę ekonomii myślenia, gdyż opiera się na zbyt dużej

2 Okazało się, że propozycja (iv), obejmująca tzw. problem transformacji wartości w ceny i tzw. prawo wartości, była ulubionym celem ataków nie tylko przeciwników marksizmu (E. Boehm-Bawerk, P. Samuelson), ale także jego sympatyków (J. Robinson, P. Sraffa). To właśnie ustalenia tych ostatnich z „zaprzyjaźnionego” programu badawczego z Cambridge w Wielkiej Brytanii miały dowieść, że jest ona zbędna nie tylko w roli teorii cen względnych, ale też w realizacji celu, jaki przyświecał Marksowi, czyli w wykazaniu wartości dodatkowej (i wyzysku), generowanej wyłącznie przez pracę produkcyjną. Propozycja (iii) dotycząca problemu wartości siły roboczej opartej na pracy abstrakcyjnej - tego, co jest żywą pracą niezbędną do wytworzenia siły roboczej (praca abstrakcyjna mierzona nakładami najemnej pracy żywej w postaci społecznie niezbędnego czasu pracy żywej, czy też praca społeczna mierzona nakładami nieodpłatnej pracy bezpośredniej) - stosunkowo rzadko poddawana była krytyce (O. Lange). Natomiast propozycje (ii) i (i) marginalizowano lub zupełnie pomijano. 
liczbie pojęć, że część pojęć nie spełnia warunku intersubiektywnej sprawdzalności, że w ewidentny sposób narusza tzw. prawo Hume’a, zawiera bowiem mnóstwo przypadków nieuprawnionej ingerencji oceniających sądów wartościujących $\mathrm{w}$ formułowanie teorii opisowych, w związku z czym ma stanowić raczej przykład teorii praw natury ${ }^{3}$ (zob. Habermas 1987, 210). Innym razem dostrzegano pewien jej potencjał, który mógłby zostać wykorzystany jedynie w wyniku rewizji jej podstaw teoretycznych, która miała polegać albo na oparciu omawianej teorii na produktywności per se, a nie na prostej pracy żywej (zob. Habermas 1983), albo na jej interpretacji w kategoriach metodologicznego narzędzia translacji pojęć z języka teorii działania na język z zakresu teorii systemów (Habermas 1999, 604-616).

Można zaryzykować stwierdzenie, że słysząc nazwę „teoria wartości”, większość reprezentantów współczesnej ekonomii głównego nurtu w najlepszym przypadku potraktuje ją jako doktrynę niespełniającą warunków stawianym propozycjom naukowym, gdyż dotycząca nieobserwowalnej struktury gospodarki w świecie, w którym przecież panuje powszechne przekonanie, iż wszystko jest dostępne zmysłom. Wśród zwolenników marksowskiej wersji LTV takie negatywne nastawienie wobec tej propozycji często interpretowano w kategoriach postawy wyrastającej z teoretycznej bezradności, ideologicznego zaślepienia, zawodowej arogancji, osobistej frustracji, prozaicznego braku czasu lub zwykłej pogardy dla filozoficznej i metodologicznej analizy. Wszystko to miało generować i wzmacniać postawę „nieczułości” na kwestie, które podnosi teoria wartości (a już na pewno ta oparta na pracy). Dlatego dla wielu krytyków najlepszym wyjściem było jak najszybsze przejście obok poruszanej teorii i poświęcenie czasu mającej spełniać warunki stawiane propozycjom naukowym pozytywnej analizie kształtowania się cen i oczyszczającemu rynek mechanizmowi równoważenia się popytu i podaży ${ }^{4}$.

3 Odpowiadając na tego typu zarzut, wystarczy w tym miejscu przypomnieć, że Marks stanowczo zaprotestował na łamiący prawo Hume’a, a zgłoszony przez socjalistów ricardiańskich postulat, iż „całkowity produkt powinien przysługiwać pracy". Co więcej, odciął się od niego, gdyż uważał go za nienaukowy i oparty na resentymencie. Zdaje się więc, że świadomy był tego, iż jeśli teoria ekonomiczna chce być teoria, to przede wszystkim musi mieć charakter opisowy, a oceniające sądy wartościujące oraz zdania formułujące normy i zalecenia nie moga należeć do takiej teorii pod groźbą popełnienia błędu naturalistycznego. Stąd postulatu socjalistów ricardiańskich nie mógł Marks uznać jako teorii ekonomicznej. Jednak w przypadku klasyków ekonomii politycznej występujące $\mathrm{w}$ ich dociekaniach metodologiczne „sądy wartościujące mogą być oparte między innymi na rzeczywistych założeniach, w taki sposób, że dopuszczalność opisowych stwierdzeń może mieć bardzo znaczący wpływ na [...] sądy wartościujące” (Sen 1978, 182). Oczywiście, ustalenia klasyków ekonomii politycznej moga być kojarzone z określonym stanowiskiem etycznym, lecz nie jest to ich teoretycznym fundamentem. Zresztą wszelkie zarzuty świadczą tylko o dużej żywotności omawianej teorii. Wielokrotnie ogłaszano jej ostateczną klęskę, lecz za każdym razem broniła się przed zesłaniem na wysypisko idei ekonomicznych.

4 Pomija się tutaj kwestię, na ile teorie i modele z obszaru współczesnej ekonomii głównego nurtu spełniają wymogi stawiane propozycjom naukowym. Nawet jeśli uznaje się, że spełniaja, to powstaje problem kryteriów, na podstawie których się to ocenia. Okazuje się, że dyscyplina ekonomii nie jest tak samodzielna względem innych dyscyplin, teorie (modele) często nie są tak spójne logicznie, a pomiar tak dokładny empirycznie, jak by sobie tego życzyli reprezentanci głównego nurtu. Należy jednak przyznać, że dotyczy to w równym, a czasami nawet w większym stopniu, innych szkół ekonomicznych (nie wyłączając marksistowskiej). 
Z czego wynika taka obojętność głównego nurtu ekonomii na problemy klasycznej teorii wartości? Jednym z powodów jest to, iż - jak podkreśliła Joan Robinson (zob. 1960, 49-58; 1953, 22-23) - na przełomie XIX i XX wieku Alfred Marshall, jeden z ojców ekonomii neoklasycznej, nie tylko dostarczył innej odpowiedzi na pytanie nurtujące klasyków ekonomii politycznej, ale też po prostu zmienił samo to pytanie na pytanie przez małe „p” następującego typu: „Dlaczego jajko kosztuje więcej niż filiżanka herbaty?”. Mimo że jest to „małe” pytanie, to odpowiedź na nie była na tyle skomplikowana, że zajęła zwolennikom Marshalla blisko pięćdziesiąt lat. W tym czasie nie próbowano nawet powrócić do pytania przez wielkie „P”, stawianego wcześniej przez Smitha, Ricarda i Marksa. Dopiero Keynes wrócił do oryginalnego pytania i zaczął rozumować w makroekonomicznych kategoriach pełnego zatrudnienia, efektywnego popytu, produkcji całkowitej, czy też udziału płac w dochodzie narodowym, nie przejmując się zbytnio względną ceną filiżanki herbaty. Niestety, nie odrzucając teorii płac opartych na produkcie krańcowym, nie dość konsekwentnie przejmował się także nierównym podziałem dochodów. Należy jednak przyznać, że Keynes w swej Ogólnej teorii... przychylnym okiem patrzył na znaczenie marksowskiej teorii cen względnych opartych na kosztach pracy w krótkim okresie ${ }^{5}$, a to z racji tego, że uznawał koszty pracy za wyjątkowy koszt społeczny.

Ostatnią odsłoną teorii wartości w głównym nurcie ekonomii była opublikowana w 1959 roku w USA praca Theory of Value autorstwa Gerarda Debreu. Od tamtego czasu nie można było oprzeć się wrażeniu, że nazwę „teoria wartości” zaczęto stosować po prostu jako synonim teorii kształtowania się cen. Stanowi to jednak nieuprawnione uproszczenie, a nawet przejaw zbyt daleko posuniętego redukcjonizmu, ponieważ nadal zasadne jest analizowanie gospodarki za pomoca trzech perspektyw (zob. Wolfstetter 1973, 788). Dlatego w tym celu należy ostrożnie rozgraniczyć trzy płaszczyzny gospodarki ${ }^{6}$, co - jak się zdaje - było jedną z intencji Quesnaya, Smitha, Ricarda i Marksa:

(i) stosunki produkcji, stanowiące system nakładów i wyników w ujęciu wielkości fizycznych;

5 Nie zmienia to jednak faktu, czego nie mogli zapomnieć Keynesowi jego „postkeynesowscy” kontynuatorzy, że ten bezwiednie, chociaż bez większych konsekwencji, przejął od Marshalla całkowicie nieprzystającą do realiów kapitalistycznego rynku pracy i instytucji pracy najemnej ideę krańcowej przykrości pracy i krańcowego produktu pracy w roli czynników, które wpływają na wielkość zatrudnienia (czy to w formie intensive margin, czy to extensive margin) i bezrobocia (zob. Robinson 1974, 84-93).

6 Przyjmuje się tutaj, że te trzy systemy analizy nie są alternatywnymi dziedzinami rzeczywistości gospodarczej, lecz stanowią różne możliwości opisu tego samego systemu gospodarki kapitalistycznej. Każdy z nich jest w takim samym stopniu realny, każdy z nich rzuca światło na inny aspekt tej samej rzeczywistości, stąd wszystkie są niezbędne i moga powiększyć zakres naszej wiedzy o gospodarce. Każda teoria wartości związana jest w sposób oczywisty $\mathrm{z}$ teoria cen, teorią nakładów-wyników oraz matematycznym ujęciem relacji chrematystycznych (związanych z działalnością pieniężno-zarobkowa), katalaktycznych (związanych z wymiana) czy fizycznych między towarami (rynek wymiany towarów konsumpcyjnych), czynnikami produkcji (rynek wymiany czynników produkcji) oraz nakładami produkcyjnymi (zorganizowana hierarchicznie sfera produkcji). Nie oznacza to jednak, że te aspekty zupełnie ją wyczerpuja. 
(ii) stosunki wartości, stanowiące system stosunków między osobami określanych w ujęciu jednostek [czasu] pracy;

(iii) stosunki cen, stanowiące system relacji wymiany między towarami określanych w ujęciu pieniężnym.

Wydaje się, że z podobnych założeń wychodzili klasycy ekonomii politycznej. Należy pamiętać, że wraz ze swoimi propozycjami teoretycznymi byli oni swego rodzaju przykładami danej klasy teorii wartości, stawiającej pytania przez duże „P” i związanej z danym etapem rozwoju możliwości pomiaru różnego rodzaju wielkości ekonomicznych i danym etapem rozwoju kryteriów tego, co jest osiąnięciem naukowym, a co nim nie jest (Mirowski 1989, 143). Stąd wszelkiego rodzaju komentarze - wystosowywane z perspektywy czasu w postaci albo uwag, albo „racjonalnych rekonstrukcji” klasycznych teorii wartości, głoszące, że Marks to „pomniejszy spośród postricardian” oraz że „wszystko było już u Smitha”, a już na pewno u Ricarda - zdają się albo nierzetelnymi imputacjami, albo ,irracjonalnymi rekonstrukcjami”.

Tym, co rzeczywiście łączyło Quesnaya, Smitha, Ricarda i Marksa, była taksonomia gospodarki i jej podział na trzy sfery: produkcji, wymiany i konsumpcji, przy czym dla nich wszystkich rdzeniem całego procesu gospodarczego była „produkcja”. To właśnie w tej sferze działała zasada generująca albo „bogactwo narodów” (Smith), albo „prawa rządzące podziałem produktu” (Ricardo), albo „ekonomiczne prawa ruchu nowoczesnego społeczeństwa” (Marks). Przyjmuje się, że początki teorii wartości sięgają czasów Petty'ego oraz fizjokratyzmu i Quesnaya, który wyrósł w atmosferze stworzonej we Francji przez Kartezjusza, co niewątpliwie wpłynęło na jego rozważania ekonomiczne (Mirowski 1989, 155 n.). Istotne jest, iż Quesnay produkcyjną rolę przypisał wyłącznie pracy na roli, poprzez która miał być generowany produkt dodatkowy w sensie nadwyżki wytworzonej wartości ponad koszty produkcji. Z czasem zaczęły się pojawiać różnice w teoretycznym podejściu do zagadnienia wartości w zależności od kraju, wartości i norm kulturowych, struktury społecznej, struktury gospodarki i poziomu uprzemysłowienia, struktury zatrudnienia itp. Okazało się, że odpowiednie warunki: odpowiednia struktura społeczna - dzięki rewolucjom przemysłowym i migracjom wewnętrznym - oraz odpowiedni klimat intelektualny - dzięki „,szkockiemu oświeceniu" - został stworzony na Wyspach Brytyjskich, gdzie powzięto i rozwinięto fizjokratyczną koncepcję wartości. Jak stwierdził Philip Mirowski (1989, 164), to właśnie Smith jest głównym podejrzanym w sprawie przeszmuglowania rodzącej się kontynentalnej ekonomii na podwórko Newtona. Przy czym, „olbrzymim krokiem naprzód ze strony Smitha było to, że odrzucił wszelką ograniczoność działalności rodzącej bogactwo - [biorąc] pracę jako taką, ani manufakturowa, ani komercyjną, ani rolniczą, lecz zarówno jedną, jak drugą" (Marks 1953, 251).

Mimo że Smith czerpał w wielu kwestiach inspiracje z fizjokratyzmu, to jednak nie podzielał w wystarczającym stopniu skłonności Quesnaya do prowadzenia pomiaru i rachunku 
w kategoriach rzeczywistych kosztów w ujęciu fizycznym, które ostatecznie miały odnosić się do jednostek utrzymania niezbędnych do wytworzenia towarów. Takie rzeczywiste koszty w ujęciu fizycznym („quasi-obiektywnym”) stoją w opozycji do rzeczywistych kosztów w ujęciu psychologicznym („quasi-subiektywnym”), zastosowanych później np. przez Marshalla i jego kontynuatorów. Zdaniem włoskiego ekonomisty Piera Sraffy to właśnie wraz ze Smithem rozpoczęła się stopniowa „degeneracja ekonomicznego pojęcia kosztu i wartości”. „To wyłącznie Petty i Fizjokraci dysponowali poprawnym pojecciem kosztu w jednostkach «bochenka chleba». Później ktoś zaczął mierzyć go w jednostkach pracy, z racji tego, że codzienna praca wymaga takiej samej ilości pożywienia. Następnie zaczęto traktować koszt jako w gruncie rzeczy ilość pracy. Dalej, Smith zinterpretował pracę jako «wysiłek, trud i znój», który stanowi «rzeczywisty koszt» i «niewygodę». Następnie, Ricardo wrócił do pracy, lecz nie dość konsekwentnie, a Marks poszedł jedynie tak daleko jak Ricardo. Dalej Senior wynalazł «Wstrzemięźliwość», a Cairnes połączył wszelkie koszty (pracę, wstrzemięźliwość i ryzyko) jako poświęcenie. Później to Davenport, Cassel i Henderson poczynili ostatni już krok, jednak cały czas w złym kierunku” (Sraffa D3/12/4, cyt. za: Bellofiore 2010, 10-11).

Sraffa dostrzegł pewne trudności w stosowaniu pojęcia pracy ${ }^{7}$, tak w klasycznym okresie ekonomii politycznej, jak i później. Zdaje się, że wystarczająco zdawał sobie sprawę, że „praca” to przedmiot typu logicznego wyższego rzędu i dlatego może podlegać dalszej redukcji do postaci przedmiotu logicznego niższego rzędu ${ }^{8}$ W takiej sytuacji rzeczywiście istnieje niebezpieczeństwo, że Smithowski „wysiłek, trud i znój” niesie ze sobą ryzyko sprowadzenia „pracy” do kwestii psychologicznego i nie-obiektywnego kosztu. „Praca” jako „poświęcenie” - standardowe, milczące założenie w kanonicznym modelu popytu na pracę i podaży pracy stanowi pierwszy krok ku analizie w kategoriach subiektywnej „przykrości”. Należy jednak pamiętać, że o ile pojęcie pracy stosowane przez Ricarda rodzi podobne podejrzenie, aczkolwiek nie w takim stopniu jak u Smitha, o tyle pojęcie stosowane przez Marksa całkowicie odbiega od Smithowskiego „trudu i znoju”. Wobec tego początkowe stwierdzenie Sraffy, iż „Ricardo wrócił do pracy, lecz nie dość konsekwentnie, a Marks poszedł jedynie tak daleko jak Ricardo" nie do końca oddawało teoretyczne różnice między Marksem a Ricardem. Wprawdzie

7 Na trudności, jakie wiążą się z „klasycznym” pojęciem pracy w sensie prostej pracy fizycznej, mierzonej za pomocą niezróżnicowanej jednostki czasu pracy, wskazali także reprezentanci dwóch różnych szkół ekonomicznych: (i) teorii kapitału ludzkiego (zob. Schultz 1962); (ii) ekonomii postmarksowskiej (zob. Bowles i Gintis 1977).

8 W różnych szkołach z zakresu teorii ekonomii popularne są różne techniki analitycznego redukowania „pracy” do kategorii niższego rzędu w postaci: (i) płacy realnej, (ii) krańcowej przykrości pracy i krańcowej użyteczności dochodu, (iii) krańcowego produktu pracy, (iv) wartości koszyka artykułów płacowych (wartość pracy zawartej w koszyku towarów konsumowanych przez pracownika, które sprowadza się do ilości środków utrzymania niezbędnych do reprodukcji siły roboczej pracownika w ciągu jednego dnia), (v) udziału płac w produkcie netto przyjmujący formę płac nominalnych (wartość pracy rozporządzalnej przez płacę nominalna), czy też (vi) wielkość wartości wyrażonej w jednostkach pracy abstrakcyjnej, czyli społecznie niezbędnym czasie pracy żywej, jaki pracownicy muszą przeznaczyć na wytworzenie niezbędnych produktów. 
nieco później Sraffa przyznał, że marksowskie pojęcie pracy „było wciąż w wielu przypadkach ekwiwalentem” (Sraffa D3/12/4, 5, cyt. za: Bellofiore 2010,11) pojęcia „rzeczywistego kosztu” w ujęciu fizycznym, to jednak nie przydał żadnego znaczenia różnicy między Marksowską jednostką społecznie niezbędnego czasu pracy a Ricardiańską jednostką rzeczywistego czasu pracy 9

Przyjmując za kryterium rodzaj pytania, na jakie chce się odpowiedzieć, oraz pojęcie kosztu, jakim się dysponuje, w tradycji ekonomicznej można wskazać dwa typy teorii wartości ${ }^{10}$ : (i) sięgającą Petty'ego i fizjokratów, dla których koszt to zasób fizyczny środków materialnych (np. pożywienia dla pracowników) wymagany do wytworzenia towaru; oraz (ii) sięgającą Marshalla (a nawet Smitha), dla którego koszt produkcji to suma wysiłków i poświęceń, jakie niesie ze sobą każdorazowe powstrzymywanie się od konsumpcji, i praca, jaka jest wymagana do wytworzenia towaru (Sraffa D2/4, 18, cyt. za: Bellofiore 2010, 11). Według Sraffy „fatalnym błędem Smitha, Ricardo i Marksa było potraktowanie „pracy” jako wielkości w ujęciu ilościowym, która miała być mierzona w godzinach lub kilowatach ludzkiej energii i zliczana do postaci wartości [...] Wszystkie późniejsze problemy analityczne i nie tylko były spowodowane przez ten niewielki początkowy błąd, który skumulował się w procesie dedukcji (np. o stwierdzeniu, że pożywienie pracownika równa się ilości pracy można powiedzieć, że jest co najwyżej prawie prawdziwe)" (Sraffa D3/12/11, 36, cyt za: Bellofiore 2010, 12).

Źródeł tych problemów Sraffa upatruje w funkcjonowaniu, przynajmniej od czasu powstania klasycznej ekonomii politycznej, dwóch znaczeń pracy ludzkiej: (i) „źródła” wartości [wymiennej], która tworzy całkowity produkt i wartość; oraz (ii) jednego z czynników produkcji

9 Zdaniem Sena „ważnym rozróżnieniem jest to pomiędzy rzeczywistym czasem pracy a «społecznie niezbędnym» czasem pracy. Ten pierwszy jest czysto faktyczny, podczas gdy drugi obejmuje ,warunki kontrfaktyczne”: praca, która byłaby «potrzebna do wytworzenia jakiejś wartości użytkowej w istniejących społecznie normalnych warunkach produkcji i przy społecznie przeciętnym stopniu umiejętności i intensywności pracy» (Marks 1951, 41). Obie formuly nadają szczególne miejsce «osobistej partycypacji», lecz czynią to w nieco odmienny sposób. Pierwsza formuła opisuje rzeczywistą partycypację, podczas gdy druga skupia się na stopniu partycypacji, jaki, w normalnych warunkach panujących w tym społeczeństwie, byłby niezbędny. Aby precyzyjnie przedsięwziąć jedną z tych dwóch formuł, kryteria selekcji muszą dotyczyć nie tylko skupienia się na osobistej partycypacji, ale także muszą uwzględniać wybór pomiędzy „tym, co rzeczywiste” a „tym, co normalne” (Sen 1978, 178).

10 Bez wątpienia istnienie takich dwóch typów teorii wartości, jak również dwóch sposobów definiowania pracy („techniczny czynnik produkcji” i „działalność twórcza”) zbiega się ze stwierdzeniem Amartyi Sena, iż „można wykazać, że nowoczesna ekonomia ma dwa odrębne źródła. Jedno z tych źródeł odnosi do filozofii, a w szczególności do etyki, i istnieje długa tradycja, w której wkład do ekonomii został wniesiony przez ludzi, którzy byli głęboko zainteresowani filozofią moralną. Z łatwością można zarysować taką linię począwszy od Arystotelesa, aż po Adama Smitha, Johna Stuarta Milla, Henry’ego Sidgwicka, Francisa Edgewortha, Knuta Wicksella, Alfreda Marshall i A. C. Pigou. Inne źródło odnosi do nauk przyrodniczych i inżynierii, a tutaj można mówić o tradycji obejmującej takie nazwiska jak Petty, Quesney, Lavoisier, Ricardo, Cournot, Walras i inni. Podczas gdy pierwsze źródło umożliwia połączenie ekonomii ze złożonością ludzkiego zachowania i refleksji, to drugie prowadzi do podkreślania problemów technologii, gustów, relacji nakłady-wyniki i innych tego typu współzależności. Żadnej z tych tradycji nie powinno zależeć, na tym, aby dyscyplina ekonomii zerwała z tą drugą tradycją" (Sen 1991, 76). 
(wówczas jednostka godziny pracy lub ilości pracy jest sensowna tylko w tym drugim znaczeniu). Stwierdza dalej, iż Ricardo i Marks w swej kategorii „ilość pracy” pomieszali przywołane dwa znaczenia pracy ludzkiej [pracy w sensie źródła wartości i w sensie jednego z czynników produkcji]. W konsekwencji, zdaniem włoskiego ekonomisty, Ricardo i Marks w sposób nieuprawniony stosowali „ilość pracy” w tym pierwszym znaczeniu pracy ludzkiej, która według niego jest ilością niemierzalną, a nawet w ogóle nie stanowi „ilości”. W jego mniemaniu zasadne jest użycie kategorii „ilości pracy” tylko w odniesieniu do pracy jako jednego z czynników produkcji (Sraffa D3/12/11, 64, cyt. za: Bellofiore 2010, 12). Okazuje się jednak, że Sraffa krytykuje tutaj wyłącznie zastosowanie przez Marksa jednostki „ilości pracy” w dwóch kontekstach: (i) teorii wartości względnej (cen względnych), zgodnie z którą wartość poszczególnego towaru równa się ilości pracy wydatkowanej na jego wytworzenie, oraz (ii) teorii wartości dodatkowej (wyzysku) głoszącej, że zysk jest generowany przez dodatkową ilość wydatkowanej pracy. Jednakże, jak zostanie pokazane, Marks stosował pojęcie pracy także w trzecim kontekście teorii wartości.

Niemniej można w tym miejscu podtrzymać pytanie, czy Sraffa, ale też Robinson, Kołakowski, Myrdal, Gordon, Arendt czy ostatnio Steedman i Blaug, mają rację, twierdząc, że Smith, Ricardo, a zwłaszcza Marks pomieszali dwa znaczenia zarówno terminu „wartość”, jak i terminu „praca”. Na tak postawione pytanie postaramy się odpowiedzieć nieco później podczas omawiania problemu wartości i problemu pracy ${ }^{11}$.

\section{Problem marksowskiej wersji teorii wartości opartej na pracy w tradycji marksistowskiej}

Powszechnie wiadomo, że teoria wartości opartej na pracy, niegdyś powód do dumy całego środowiska marksistowskiego (zob. Meek 1958), z upływem lat stawała się przedmiotem jego zakłopotania. Co więcej, jej dość powszechne odrzucenie w obrębie tradycji lewicowej zarówno wśród filozofów, jak i ekonomistów - doskonale wpisuje się w szersze zjawisko, zwane przez historyków idei „kryzysem marksizmu” (zob. Korsch 1974; Althusser 1978). Wówczas to filozoficzna część środowiska marksistowskiego ${ }^{12}$, chcąc uwolnić marksizm od

11 W tym miejscu należy zaznaczyć, że krytycy (w tym Sraffa) nie dostrzegli trzeciego znaczenia, w jakim Marks mógł stosować termin „praca” i jednostkę „,społecznie niezbędnej godziny pracy”. Oprócz (i) czynnika produkcji wyrażanego w specyficznych jednostkach czasu pracy oraz (ii) przyczyny wartości względnej i źródła wartości dodatkowej, Marks mógł mieć na myśli także pracę w sensie (iii) miernika wartości bezwzględnej, której jednostką nie była po prostu rzeczywista godzina pracy, lecz „społecznie niezbędna godzina pracy” żywej. Ten ostatni przypadek zostanie rozwinięty w dalszych rozważaniach. Z tego wynika, że nie doceniono również doniosłości trzeciego znaczenia, w jakim Marks mógł stosować termin „wartość”. Oprócz (i) wartości względnej, (ii) wartości dodatkowej, Marks mógł mieć na myśli (iii) wartość bezwzględną.

12 M.in. A. Gramsci, K Korsch, G. Lukacs, M. Horkheimer, T. Adorno, A. Gorz, L. Althusser, J. Habermas, L. Kołakowski, A. Heller czy J. P. Sartre. 
wad tzw. ekonomizmu, odcięła go także od zalet teorii ekonomii. Z kolei ekonomiczna część środowiska lewicowego ${ }^{13}$, i nie tylko ${ }^{14}$, chcąc uwolnić ekonomię marksistowską od słabości teorii wartości opartej na pracy, odcięła ją również od wyjątkowego statusu przypisywanego pojęciu pracy. W konsekwencji uwolniono teorię wartości opartej na pracy od zarzutu o domniemaną logiczną i matematyczną sprzeczność (zob. m.in.: Shaikh 1998; Foley 2000; Duménil 1983-1984), ale jedynie po to, aby skazać ją następnie na zapomnienie za jej rzekomą zbyteczność ${ }^{15}$.

Jednym z powodów filozoficznego odejścia od teorii wartości było zawężenie LTV do teorii cen względnych, co spowodowało, że całe pokolenia ekonomistów marksistowskich uwikłały się w „scholastyczny” spór, próbując rozwiązać matematyczny w swej naturze „problem transformacji” wartości w ceny. W ten sposób stracono z oczu inne, równie ważne aspekty marksowskiej teorii wartości. Nie twierdzi się tutaj, że marksowska wersja stoi na straconej pozycji w debacie o relacjach cen. Niemniej jednak, by móc uznać ją za pełnoprawna reprezentantkę teorii cen względnych, musi ona dowieść, że „cena towaru jest równa ilości pracy uprzedmiotowionej w nim podczas produkcji [i], że konkurencja wymusza taki podział zasobów produkcyjnych między różne gałęzie, że względne ceny w długim okresie stają się proporcjonalne do nakładów pracy” (Blaug 2000, 246). Dlatego interpretacja spopularyzowana przez polskiego ekonomistę Oskara Langego (1975) uczyniła z omawianej teorii wartości w gruncie rzeczy niedoskonały przypadek Walrasowskiej teorii równowagi ogólnej. Wielu komentatorów uznało, że czymkolwiek by była marksowska wersja LTV, to z dużą dozą prawdopodobieństwa można stwierdzić, że nie jest ona ilościową teorią relacji cen i gdzie indziej należy szukać jej ewentualnej naukowej doniosłości.

Konsekwencjami reakcji filozoficznej części środowiska marksistowskiego na taki „scholastyczny” spór w obronie czegoś, co według niektórych komentatorów wcale nie było warunkiem koniecznym do utrzymania spójności ekonomii marksowskiej ${ }^{16}$, były marginalizacja

13 M.in. J. Robinson, P. Sraffa, W. Leontief, J. von Neuman, G. Myrdal, M. Morishima, I. Steedman.

14 Zdaniem przedstawiciela ekonomii głównego nurtu Paula Samuelsona „po części prawdziwe jest stwierdzenie, iż ekonomia marksowska jest zbyt skomplikowana, by zostawić ją w rękach marksistów" (Samuelson 1957, 911).

15 Wydaje się, że część środowiska marksistowskiego, utożsamiając teorię wartości z teorią relacji cen, zbyt pochopnie porzuciła teorię opartą na pracy, gdzie indziej doszukując się rdzenia projektu marksowskiego. Jednym z wyjątków był Maurice Dobb, który w swoich badaniach nad „wymogami stawianymi teorii wartości” wyszedł z propozycją obszernej listy wymagań: „niezbędnym warunkiem teorii wartości jest to, że musi ona rozwiązać problem podziału (tj. określenia ceny siły roboczej, kapitału i ziemi), a także problem wartości towaru; musi tego dokonać nie tylko dlatego, że problem podziału jest zasadniczą, czy wręcz główna, częścią praktycznego dociekania, którą zajmuje się ekonomia polityczna, ale także dlatego, że jednego nie da się określić bez drugiego" (Dobb 1937, 9).

16 Tego typu stanowisko prezentowali reprezentanci szkoły neoricardiańskiej (sraffianie) oraz postkeynesistowskiej, mimo że interpretuje się ich jako „sojuszników” środowiska marksistowskiego w zamiarze uzasadnienia istnienia wartości dodatkowej w gospodarce. 
znaczenia gospodarki i pozostawienie tej sfery naturalizującym kapitalizm ekspertom neoklasycznej „ponurej nauki”17 lub naturalnemu biegowi rzeczy. Wskutek takiego antylaborystycznego, antyekonomistycznego i kulturalistycznego „ukąszenia” nawet jeśli nie bagatelizowano gospodarki, to niepoprawnie ja rozumiano. Co ciekawe, trzech czołowych przedstawicieli marksistowskiej ekonomii teoretycznej: Maurice Dobb, Ernest Mandel i Paul Sweezy, pozostali nieczuli na „kulturalistyczną" krytykę tradycyjnego stanowiska marksowskiego. W rezultacie nastapiła osobna ewolucja marksowskich tradycji filozofii kultury (i polityki) oraz teorii ekonomii, które przez długi czas pozostawały głuche na swoje argumenty. Ta pierwsza tradycja krytykowała druga za „ekonomistyczny determinizm”, a sama była oskarżana o „hipostazowanie nadbudowy”. Po latach okazało się, że najlepszą drogą naprzód było przemyślenie stosunku bazy do nadbudowy (i samych treści tych kategorii, a zwłaszcza tego, czym jest gospodarka) (Bowles 1985, 509; zob. też odpowiedź: Wolff i Cullenberg 1986, 126-135). Pociągało to za sobą konieczność zrewidowania stosunku do LTV w jej klasycznej postaci. Przedmiotem tego typu rewizji były (jakościowe) treści wiązane z pojęciem wartości i pojęciem pracy oraz (ilościowe) procedury generowania nowych jednostek miary wartości i pracy. Przykładów takiej strategii teoretycznej jest wiele. W tym miejscu wystarczy przywołać choćby propozycje rewizji LTV zgłoszone przez Samuela Bowlesa i Herberta Gintisa lub Riccarda Bellofiorego.

Jak w dyskusjach wokół marksizmu, „wiele nieporozumień wynika z braku świadomości, na czym polegały osobliwości metody Marksowskiej” (Szacki 2004, 241), tak w dyskusjach wokół marksowskiej wersji LTV wiele nieporozumień wynika z faktu, że jej komentatorzy odmiennie, a często nawet opacznie, odbierają intencje jej twórcy i jego zwolenników ${ }^{18}$. Zdaje się, że przeważająca część nieporozumień dotyczyła i nadal dotyczy znaczenia i zakresu terminów: „wartość”, „praca” oraz „teoria”. W niniejszych rozważaniach istotnym założeniem jest to, że problem z „wartością” i „pracą” nie jest w pierwszej kolejności problemem czysto empirycznym, czy też problemem powzięcia adekwatnych lub nieadekwatnych metod pomiaru, który wiąże się z dostarczeniem pełniejszych informacji ${ }^{19}$, ale

17 Przykładem takiego nastawienia niech będzie choćby Jürgen Habermas, dla którego podsystem gospodarki stanowił, na pewnym etapie rozwoju jego myśli, wolny od norm i wartości podsystem działania celowo-racjonalnego z wszelkimi tego konsekwencjami dla analizy gospodarki.

18 Rację ma niewątpliwie Sen, który zauważa, że uderzająca jest ludzka zdolność do przeinaczania bądź do złego rozumienia tego, o co innym chodzi. W konsekwencji niestosowne i ostre ataki moga zaczać mieszać się z adekwatną i przenikliwą krytyką. Dlatego tak istotna jest potrzeba oddzielenia tych dwóch postaw (Sen 1991, 67).

19 Zgodnie z takim stanowiskiem problemy wartości i pracy są kwestiami pomiaru, które jak najbardziej można rozwiązać. Według takiego stanowiska, które moglibyśmy nazwać „statystycznym optymizmem”, wszelkie problemy sprowadzają się do technicznych problemów, wynikających z niedokładności danych lub niedoskonałości technik statystycznych. Z tego właśnie powodu rezultat nie odzwierciedla dokładnej miary nieznanej, aczkolwiek istniejącej i teoretycznie uzasadnionej, wielkości zakładanej „wartości”. 
jest raczej problemem pojęciowej jasności ${ }^{20}$. Dlatego też szczególnie ważna staje się kwestia precyzji definiowania, a dopiero potem znalezienia jednostki miary, samego pomiaru omawianych wielkości oraz jej empirycznego testowania. Tylko wtedy, gdy dana teoria wytwarza klarowne pojęcia, możliwa staje się ich adekwatna operacjonalizacja i ewentualna dalsza krytyka według kryteriów stawianych propozycjom naukowym.

\section{Problem wartości i jej pomiaru}

„Wartość na nic się nie zda. Nie posiada ona żadnej treści operacyjnej. To tylko słowo”. W ten sposób Joan Robinson zakończyła swój drugi wykład z filozofii ekonomii, zatytułowany The Classics: Value (Robinson 1974, 47). Wcześniej w elegancki sposób odrzuciła sposób użycia LTV przez Marksa jako metafizyczny ${ }^{21}$. Latwo jest odgadnąć, że w rozprawie angielskiej ekonomistki z ortodoksyjną ekonomią marksistowską wywołanymi wcześniej do tablicy „współczesnymi jej marksistami” byli Maurice Dobb (brytyjska szkoła marksizmu), Paul Sweezy (amerykańska szkoła marksizmu) oraz Ernest Mandel (kontynentalna szkoła marksizmu), którzy zajmowali się obszernie tą samą kwestią w swoich najważniejszych książkach ${ }^{22}$.

Opinia wyrażona przez Joan Robinson nie była jednak odosobniona. W podobnym tonie wypowiedział się później m.in. w swoich Głównych nurtach marksižmu Leszek Kołakowski, według którego „[w]artość w sensie Marksa jest niemierzalna, to jest, nie można podać wartości jakiegokolwiek towaru w jednostkach niezbędnego czasu pracy" (Kołakowski 2000, 390). Pierwszym powodem takiego teoretycznego i statystycznego pesymizmu Kołakowskiego było

20 Takie stanowisko, chociaż nie „podkopuje” poprzedniego, to jednak przyznaje pierwszeństwo problemom epistemologicznym i metodologicznym, które są niezwykle trudne do przezwyciężenia. Według takiego stanowiska, które moglibyśmy nazwać „teoretycznym puryzmem”, najistotniejsza część problemów sprowadza się do tego, że nieznana „idealna” wartość, którą chcę poznać za pomocą statystycznych szacunków, może być pozbawiona teoretycznej precyzji. Powodem takiego stanu rzeczy moga być problemy pojawiające się na etapie formułowania pojęć, modeli i teorii. Obejmuje to m.in. powszechne występowanie ze względu na aktualny stan wiedzy niepełnych definicji wielkości, która ma podlegać pomiarowi, oraz niedoskonałej realizacji definicji wielkości mierzalnej. Oczywiście, jest to powszechne zjawisko, zwłaszcza w naukach społecznych, w których definicje cząstkowe występują bardzo często. Jednym ze sposobów zmiany tego stanu rzeczy jest stosowanie definicji regulujących, co może pomóc w radzeniu sobie z dwoma rodzajami problemów nękających pojęcia teoretyczne: pierwszy to „nieostrość”, czyli brak możliwości wskazania klasy przedmiotów podpadających pod zakres danej nazwy, a drugi to „niewyraźność”, czyli brak możliwości wskazania takiego zbioru cech, za pomocą których można ją jednoznacznie scharakteryzować (nie potrafi się wskazać na treść charakterystyczna) (zob. Ziembiński 2002, 34-36; Ajdukiewicz 2006, 34-44).

21 Do kwestii tej powrócimy później, omawiając odmienne niemetafizyczne interpretacje LTV, takie jak: (i) deskryptywna, (ii) predyktywna oraz (iii) normatywna.

22 Dobb rozpoczął swoje dociekanie od pytania: „Jakie w ogóle znaczenie ma teoria wartości opartej na pracy dla struktury twierdzeń, które składają się na ekonomię polityczną?” (Dobb 1937, 3). Paul Sweezy postawił zaś pytanie o „stosunek problemu ilościowego do jakościowego w teorii wartości”, podkreślając różnicę między „wielkością wartości” a „substancją wartości” („źródłem wartości wymiennej” a „miernikiem wartości bezwzględnej”) (Sweezy 1965, 55). Zob. też: Mandel (1968). 
podejrzenie, iż pojęcie wartości nie spełnia wymogu mierzalności ze względu na trudność w obliczaniu ,pracy wydatkowanej w przeszłości” na dobra kapitałowe ('środki produkcji, narzędzia, z których przecież korzysta praca żywa i które chociaż nie tworzą nowej wartości, to jednak są niezbędne do jej wytwarzania). Krytycy przestrzegaja w tym kontekście przed kuriozalnym problemem cofania się aż do pierwszego „człowieka na ziemi”. Drugim powodem są trudności w „redukcji różnych rodzajów pracy do pracy prostej”. Jeśli wartość użytkowa siły roboczej zależy od umiejętności pracownika, to wartość danego rodzaju siły roboczej będzie zależeć od kosztów produkcji i reprodukcji jego umiejętności. Marks świetnie zdawał sobie sprawę z rzeczywistego zróżnicowania pracy konkretnej, dlatego powołał do życia pojęcie pracy abstrakcyjnej, która dopuszczała różnorodność prac konkretnych, pozostając przy tym wspólnym dla nich teoretycznym mianownikiem (wraz z miernikiem w postaci społecznie niezbędnego czasu pracy prostej). Z tego też powodu zastosował zabieg teoretyczny, w wyniku którego uznał, iż rzeczywiste różnice pomiędzy pracownikami są co najwyżej różnicami umiejętności (przy czym raczej różnicami stopnia niż rodzaju). Dla tych różnic można jednak znaleźć wspólną jednostkę miary w myśl twierdzenia, że praca wykwalifikowana (złożona) stanowi wyłącznie „wielokrotność” pracy niewykwalifikowanej (prostej). W takiej sytuacji oskarżano Marksa (np. Boehm-Bawerk), że redukcja pracy złożonej do prostej odbyła się poprzez rynkowy proces wymiany przy użyciu odpowiednich wag w postaci płac względnych. Rzeczywiście może zachodzić podejrzenie, iż Marks implicite powiązał wartość siły roboczej ze stawką realnych płac rynkowych (Bowles i Gintis 1977, 175-176). Problem w tym, że Marks nie twierdził - jak chce tego Kołakowski - że „rynek pracy żywiołowo redukuje pracę złożoną do wspólnej miary z pracą prosta” za pomoca płac realnych. Uznając, że to raczej wartość siły roboczej jest dana, a nie cena siły roboczej (płaca robocza), Marks podkreślał, że jeśli już, to za ten proces redukcji odpowiada w praktyce „proces społeczny” (Marks 1951, 47), którego w żaden sposób nie można utożsamić z rynkiem, a to dlatego, że duża część produkcji i reprodukcji siły roboczej wciąż nie odbywa się zgodnie z „logiką” kapitalistycznego rynku edukacji i pracy. Nawet jeśli można tak postapić, to wówczas pojawia się jeszcze kwestia jednostek, w jakich mierzy się wartość siły roboczej. Taką jednostką raczej nie może być stawka płacy realnej w sensie koszyka dóbr płacowych. Zreszta w ekonomii neoklasycznej płaca występuje najpierw w charakterze zachęty, motywacji, bodźca, który ma nakłonić pracownika pojawiającego się na rynku pracy do wykonania czy świadczenia pracy, gdyż - jak wiadomo zakłada się tutaj psychologiczną przykrość każdego wysiłku. Nieco inną rolę odgrywa płaca u Marksa, podobnie jak u innych klasyków, gdyż „z chwila, gdy opuszczamy tę sferę [rynku wymiany pracy i wstępujemy do przedsiębiorstwa] coś jak gdyby się już zmienia w fizjonomiach naszych dramatis personae" (Marks 1951, 187). Zanim w ogóle pojawia się kwestia motywacji i środków utrzymania (siła nabywcza płacy), fundamentalne znaczenie ma to, że ekwiwalent obiektywnych środków utrzymania jest niezbędny, żeby w ogóle dać pracownikom możliwość 
pracy i rozszerzonego reprodukowania ich umiejętności i zręczności. Z takiej perspektywy to raczej środki zatrudnienia (stopień ekwiwalencji płacy), czyli sposób wytwarzania środków wytwarzania, a nie same środki utrzymania, decydują o przynależności do określonej kategorii społecznej. Innymi słowy, spór dotyczy tego, czy płaca jest wyłącznie konsumpcyjna i nie jest w ogóle produkcyjna, ponieważ w ogóle nie tworzy bądź tworzy w bardzo wąskim zakresie bogactwo pieniężne (robotnik ma małe możliwości oszczędzania, a nawet jeśli oszczędza, to tylko po to, aby wydawać w okresach recesji i spadku płac realnych), czy też płaca jest produkcyjna. Pierwszy punkt widzenia jest zgodny z logiką kapitału, zgodnie z którą definiuje się „pracę” w sposób przedmiotowy i negatywny. Takie „uprzedmiotowione” i negatywne („nie-kapitał”) pojęcie pracy żywej (nieredukowalnej do narzędzi pracy, surowców, środków i przedmiotów pracy) stanowi zaprzeczenie przedmiotowego bogactwa pieniężnego. Praca [abstrakcyjna, ogólna] oznacza tutaj po prostu przedmiotową wartość użytkową siły roboczej dla kapitału, która w procesie cyrkulacji jest wymieniana na płacę. Pamiętajmy przy tym, że płaca nie jest produkcyjna, lecz niezbędna do konsumpcji ekwiwalentu w postaci środków utrzymania. Drugi punkt widzenia zgadza się z logiką pracy, w ramach której definiuje się „pracę” w sposób podmiotowy i pozytywny. Takie „upodmiotowienie” i pozytywne (twórcza działalność) pojęcie pracy żywej zakładają, że choć sama praca nie ma wartości wymiennej, to jednak stanowi źródło wartości wymiennej. Praca oznacza tutaj ogólną możliwość bogactwa, która potwierdza się w działaniu. Pamiętajmy, iż jest tak wyłącznie przy założeniu, że płaca jest produkcyjna. Trzeba również podkreślić, że według Marksa siła robocza ze względu na otrzymywanie za oddanie jej do dyspozycji płacy roboczej ma dla samego pracownika „wartość użytkową tylko dlatego, że jest wartością wymienną, nie zaś dlatego, że wytwarza wartość wymienną" (Marks 1986, 223). Innymi słowy, cena siły roboczej (płaca) jest dla robotnika wartością użytkową, którą musi on dalej zrealizować w celu reprodukcji swej siły roboczej23.

Należy jednak pamiętać - co Marks $(1951,181-182)$ wielokrotnie przecież podkreślał - że oprócz środków niezbędnych do utrzymania i reprodukcji (prostej albo rozszerzonej) siły roboczej wartość siły roboczej obejmuje także „pierwiastki historyczne i moralne”, koszty wychowania, wyuczenia i wykształcenia. Być może dlatego można mówić o płacy, że jest produkcyjna, gdyż jej realizacja (nie licząc niezbędnej konsumpcji środków utrzymania) umożliwia powiększenie możności, potencjału, zdolności siły roboczej w wytwarzaniu wartości użytkowych. Nie jest przy tym jasne, czy tego typu produkcyjne spożytkowanie płacy stanowi formę inwestycji, jak jest w teorii kapitału ludzkiego. Zdaje się, że Marks nie przystałby na taką propozycję. Gdyby jednak było inaczej, to mielibyśmy do czynienia z antycypacją rewolucji

23 Zdaje się, że za tą całą dyskusją pomiędzy „płacą konsumpcyjną” a „płaca produkcyjną” kryje się spór o to, czy bardziej adekwatnym określeniem fizjonomii dramatis personae jest miano kategorii z zakresu nowoczesnej ekonomii dobrobytu: „suwerenności konsumenta”, „suwerenności producenta (przedsiębiorcy) czy „suwerenności pracownika” („Producer and consumer sovereignty” 2001, 911-914; Schor 1998, 131-139). 
związanej z kapitałem ludzkim, $z$ tą różnica, że przeprowadzoną na gruncie „upodmiotowionego” pojęcia pracy, a nie „uprzedmiotowionego” pojęcia kapitału (zob. K. Nowak 2011, 166-187; 2012b, 3-24). Trzeba jednak przyznać, że nadal dyskusyjne pozostaje to, w jakich jednostkach należy podawać owe koszty produkcji siły roboczej: w ekwiwalencie towarowym, w jednostkach wartości, czy też w jakichś innych wielkościach? Zdaje się, że można Marksowi zarzucić, że w swojej teorii wartości siły roboczej: (i) nie dość konsekwentnie podtrzymywał założenie o tym, iż siła robocza nie jest towarem takim jak inne; (ii) nie wykorzystał w pełni potencjału drzemiącego w różnicy między pracą abstrakcyjną, społeczną i niezbędną.

W atmosferze tych wszystkich metodologicznych osobliwości, teoretycznych subtelności i definicyjnych niejasności stwierdzenie Marka Blauga, że „[w]artość u Marksa nie jest [...] relacją wymienną między produktami, lecz czystą abstrakcja, postulowana, a nie indukowaną na podstawie obserwacji” (Blaug 2000, 247), stanowiło dominującą interpretację marksowskiej koncepcji. Dlatego na dalszy plan zeszła interpretacja, w której definiuje się marksowską „wartość” przede wszystkim w kategoriach „stosunku pomiędzy osobami wyrażonego jako stosunku pomiędzy rzeczami” (Marks 1951, 45). Takie zaniedbanie nie znajduje zrozumienia, gdyż to stwierdzenie, że wymiana towarów stanowi „ostateczny stosunek społeczny zachodzący pomiędzy ludźmi, który zakłada, w ich oczach, niezwykłą formę stosunku pomiędzy rzeczami” (Marks 1951, 77), stanowiło punkt wyjścia opisu procesu wymiany nie tyle w kategoriach cen względnych, ile w kategoriach stosunków między osobami, powstających poprzez osobista partycypację w procesie produkcji towarów podlegających wymianie (Sen 1978).

Owe kontrowersje związane z Marksowskim pojęciem wartości prowokują do postawienia pytania, czy aby przeciwnicy i zwolennicy Marksowskiej koncepcji wartości operowali tym samym pojęciem? O jaką zatem wartość chodzi? Pomijając w tym miejscu kwestię tradycyjnego w teorii ekonomii wiązania „wartości użytkowej”24 i „wartości wymiennej” z „towarem”25, pożyteczną operacją analityczną okazuje się wyodrębnienie trzech kontekstów, w jakich pojęcie wartości pojawiało się w klasycznych teoriach wartości opartej na pracy. Okazuje się, że znaczenie „wartości” zależało zarówno od kontekstu użycia tego terminu, jak i od tego, czy była mowa o: (i) technicznych relacjach wymiennych między rzeczami (produktami, towarami) czy (ii) wertykalnych klasowych stosunkach między robotnikami a kapitalistami, czy też (iii) horyzontalnych stosunkach między różnymi

24 W wyniku tego rozróżnia się wartość użytkową towaru, czyli potencjałem produktu do zaspokajania ogólnych potrzeb. W terminologii stosowanej w nowoczesnej teorii ekonomii pojęcie „wartości użytkowej” towaru nie do końca jest tożsame z pojęciem „użyteczności”, jaką czerpie konsument, stąd duży nacisk na to, by nie używać tych kategorii zamiennie.

25 Wartość wymienną danego towaru można także określić jako ilościowy stosunek pomiędzy dwoma towarami lub jako cenę towaru w sensie wartości towaru wyrażonej w pieniądzu. 
bezpośrednimi wytwórcami (pracownikami). W związku z tym można wyróżnić następujące znaczenia terminu ,wartość”.

Wartość względna, wyrażająca ilościowy stosunek, w jakim wymieniane są towary; w ten sposób można mówić o ilościowej teorii wartości względnej opartej na pracy, która stanowi formułę wyjaśniająca mikroekonomiczne zagadnienie kształtowania się i określania cen dostępnych na rynku towarów. W ramach tej propozycji, nazywanej również teorią cen względnych opartych na pracy, twierdzi się, że stosunki wymienne pomiędzy towarami w wolnokonkurencyjnym systemie rynkowym, w którym niezależni producenci konkurują ze sobą w celu maksymalizacji własnych korzyści, określone są po prostu ilością pracy włożonej w wytworzenie tych towarów, czyli ilością pracy ucieleśnionej w towarze.

Wartość dodatkowa, wyrażająca stosunek klasy kapitalistów do klasy robotników najemnych; takie znaczenie, jakie Marks przydał wartości, w jego rozważaniach dotyczących teorii źródła i „natury” zysku jako typu dochodu znalazło wyraz w postaci teorii wartości dodatkowej opartej na pracy nieopłaconej. Stanowi ona formułę postulująca, że zysk jest „nieopłaconą pracą dodatkową” przywłaszczoną przez właścicieli środków produkcji (kapitalistów) w konsekwencji historycznego pojawienia się i rozpowszechnienia instytucji własności prywatnej i instytucji pracy najemnej, która opiera się na niekompletnej, aczkolwiek „dobrowolnej” umowie o pracę. Znana jest także pod nazwą teorii wyzysku bądź teorii nieopłaconej pracy. W gruncie rzeczy jest to teoria zajmująca się makroekonomicznymi relacjami podziału wytworzonego wcześniej w procesie produkcji dochodu całkowitego między właścicieli środków produkcji w postaci właścicieli ziemi, właścicieli kapitału i przedsiębiorców oraz pracowników najemnych, którzy dysponują wyłącznie własną siłą robocza.

Wartość bezwzględna (standardowa miara wartości), wyrażająca jakościowe stosunki między różnymi bezpośrednimi wytwórcami (pracownikami); występuje ona jako wartość ukryta i oznacza pewną, ,bezwzględną miarę, jaką można przypisać każdemu dobru gospodarczemu, niezależnie od jakiegokolwiek innego dobra gospodarczego, i że takimi bezwzględnymi miarami sa albo czas pracy nabywany wraz z towarem, albo czas pracy zawarty w towarze" (Gordon 1959, 466-467), albo społecznie niezbędny czas pracy wymagany do bezpośredniego wytworzenia towaru. Taka jakościowa teoria wartości bezwzględnej, mierzonej za pomocą pracy, stanowi formułę podkreślającą znaczenie ludzkiego zaangażowania w społecznym procesie produkcji i podziału oraz postulującą szacowanie tego zaangażowania w określonych jednostkach pracy. W ramach tej teorii, określanej także mianem teorii indywidualnego dobrobytu opartego na pracy, twierdzi się, iż jednostka staje się „zamożniejsza” w rezultacie zmiany (spadku lub wzrostu) określonej wielkości26, wyrażonej w różnych

26 Przypomnijmy, że we współczesnej ekonomii przyjmuje się, że podstawowym miernikiem wzrostu dobrobytu jest miernik wzrostu poziomu dochodu realnego. To świadczy o tym, że klasyczna teoria wartości 
jednostkach pracy. Za pomocą takich wielkości można szacować poprawę materialnej i/lub społecznej stopy życiowej. Należy przy tym pamiętać, że taka perspektywa istniała w okresie klasycznej ekonomii politycznej, a reprezentanci współczesnej teorii ekonomii „,nie pozostawili żadnego miejsca na analizy wartości bezwzględnej" (Napoleoni 1998, 35), co nie znaczy, że nie czynią w tym względzie pewnych założeń implicite.

Jeśli już komentatorzy pochylali się nad tym ostatnim znaczeniem wartości (zob. Gordon 1959, 466-467; Arendt 2000, 182; Myrdal 1953, 56-103; Robinson 1974, 29-48), to wyłącznie po to, aby odmówić mu racji bytu „w nowoczesnej ekonomii, rygorystycznie oddzielającej teorię cen od ekonomii dobrobytu" (Blaug 2000, 248). Dlatego nie spotkała się ze zrozumieniem hipoteza, zgodnie z którą dociekania oparte na wartości bezwzględnej stanowia w rzeczywistości próbę skonstruowania uproszczonego, chociaż „głębokiego”, wskaźnika dobrobytu materialnego i społecznego pracowników. Skoro jednak uznaje się, że „Smith próbował sięgnąc głębiej [niż we współczesnej teorii ekonomii - przyp. K.N-P.], wiążąc poprawę stopy życiowej ze zmniejszeniem ofiar ponoszonych w celu uzyskania danego strumienia dochodu realnego”, a „Ricardo czyni z poprawy dobrobytu ujemna funkcję ludzkiego wysiłku na jednostkę produktu” (Blaug 2000, 69-70), to również u Marksa można doszukiwać się analogicznej propozycji. Niemniej różni się ona zasadniczo od tej, która zawarta jest implicite w analizach Smitha i Ricardo, gdyż bierze pod uwagę kwestie względnego i bezwzględnego zubożenia, spadającej lub stałej stopy płac realnych, rezerwowej armii bezrobotnych oraz kształtowania się płac na podstawie wartości siły roboczej.

W związku z tym Marksowska teoria wartości bezwzględnej²7 wychodzi z założenia, że „w każdym kraju istnieje pewna średnia intensywność pracy [...], aczkolwiek jest ona

bezwzględnej opartej na pracy (rozporządzalnej, ucieleśnionej lub abstrakcyjnej) sięgała głębiej w swych badaniach aniżeli współczesne teorie dobrobytu.

27 Wydaje się, że niedostateczna możliwość opracowania marksowskiej jednostki komparatystycznej w konsekwencji osłabiła zdolność do operacjonalizacji marksowskiego pojęcia pracy (zob. Marks 1986, 491-493; autor krytykuje tu psychologiczne podejście do pracy oparte na założeniu subiektywnej ofiary). Jeśli nasza argumentacja jest - jak dotąd - poprawna, to pojawia się problem, co jest lepszym przybliżeniem wahań przeciętnej intensywności pracy? Paradoksalnie, kraje deklaratywnie odwołujące się do teorii ekonomicznych Marksa, w kontekście międzynarodowych porównań standardu życia z krajami kapitalistycznymi godziły się na oparcie badań na koncepcji wskazującej na to, „ilu godzin pracy, wynagradzanej według bieżących stawek, potrzeba było na zakup poszczególnych artykułów po bieżących cenach w każdym z tych krajów. Procedura ta zakłada między innymi, że przykrość pracy w Rosji była taka sama jak w Stanach Zjednoczonych”. I chociaż współcześnie, „niemożliwe do utrzymania jest założenie stałego nakładu subiektywnych ofiar na jednostkę wysiłku «zawsze i wszędzie» (jak u Smitha), gdyż większość z nas zgodziłaby się z twierdzeniem, że głównym elementem poprawy dobrobytu w rozwijającej się gospodarce jest malejąca cena dochodu, wyrażona w wysiłku: kiedy skraca się tydzień pracy, a rośnie płaca realna, przykrość pracy z pewnością wzrasta «zawsze i wszędzie». Stała przykrość pracy «zawsze i wszędzie» nie jest prawdopodobnie założeniem łatwiejszym do utrzymania, chociaż często się je wprowadza w międzynarodowych porównaniach stopy życia” (Blaug 2000, 70). Oddajmy jednak głos samemu Marksowi, który w swoich dociekaniach nad „prawami ruchu płacy roboczej” stwierdził, że: „Przy porównywaniu narodowych płac roboczych należy więc brać pod uwagę wszelkie czynniki określające zmiany wielkości wartości siły roboczej: koszt i wielkość najpierwszych potrzeb życiowych, naturalnych i historycznie rozwiniętych, koszt wykształcenia robotnika, rolę pracy kobiet i dzieci, wydajność pracy, jej wielkość ekstensywną $\mathrm{i}$ intensywna. Nawet najbardziej powierzchowne porównanie wymaga, ażeby przede wszystkim 
w każdym kraju inna: tu większa, ówdzie mniejsza. Te przeciętne poziomy narodowe tworzą więc skalę, której jednostką miary jest jednostka przeciętnej pracy ogólnoludzkiej [...] praca o jakości normalnej” (Marks 1951, 603). „Praca o jakości normalnej” oznacza społecznie niezbędny czas pracy, wyrażający stosunek ilości czasu pracy, jaki dany pracownik rzeczywiście wydatkuje, by zrealizować swoje reprodukcyjne i konsumpcyjne potrzeby, do ilości czasu pracy przeciętnie wymaganej, by wytworzyć ekwiwalent artykułów zaspokajających te same potrzeby. Jednostki miary, jaką dla Marksa była społecznie niezbędna godzina pracy, nie należy - jak się zdaje - mylić ani z „normowaniem pracy”, czyli techniką ustalania ilości czasu niezbędnie potrzebnego do wykonania określonego zadania ${ }^{28}$, ani też z „normą pracy” z zakresu prawa pracy, nawiązująca do uznaniowej zasady „należytej pracy”, na którą wpływają sumienność i staranność pracownika. Przez Marksowską intensywność pracy należy raczej rozumieć stopień pozyskiwania faktycznej pracy z danego zasobu siły roboczej w danym czasie pracy, czyli wielkość faktycznie wykonanej pracy (wysiłek) w określonym zakontraktowanym już czasie. W jaki sposób mierzyć i porównywać w różnym czasie i w różnych miejscach taką przeciętną intensywność pracy? Odpowiedź oraz zdolność jej pomiaru nie są łatwe, o ile w ogóle są możliwe. Zdaniem Marksa „obok mierzenia czasu pracy jako «wielkości rozciagłej» (wielkość ekstensywna) występuje obecnie mierzenie stopnia zagęszczenia"29 (Marks 1951, 442) (wielkość intensywna). Średnia intensywność pracy to nie subiektywny i uczuciowy stosunek człowieka do swej pracy (sumienność i pracowitość), ani też zawodowy stosunek człowieka do swoich umiejętności (jakość, staranność), ale strukturalny stosunek człowieka do stopnia, w jakim „realizuje, reguluje i kontroluje” dane normy pracy.

Większość komentatorów Marksa skoncentrowała się na stronniczej analizie jego teorii wartości względnej opartej na pracy ucieleśnionej w towarach lub jego teorii wartości dodatkowej, podkreślającej różnicę między wartością siły roboczej pracownika a wartością wytworzonych przez niego produktów. Pominięto niemal zupełnie to, co nazwaliśmy teoria

sprowadzić przeciętna płacę dzienną w tych samych gałęziach pracy w różnych krajach do dni roboczych jednakowej wielkości. Po takim wyrównaniu płac dziennych należy z kolei płacę dniówkową zamienić na płace od sztuki, gdyż ta ostatnia jest miernikiem wydajności pracy, jak również jej wielkości intensywnej” (Marks 1951, 602-603). ,Rozmaitość naturalnych warunków pracy sprawia, że ta sama ilość pracy w różnych krajach zaspokaja różne masy potrzeb, że więc, przy innych warunkach analogicznych, niezbędny czas pracy jest różny" (Marks 1951, 554).

28 Normowanie pracy (wartościowanie pracy, klasyfikowanie pracy) to raczej technika zarządzania i racjonalizowania, zmierzająca do usprawnienia procesu pracy i podniesienia wydajności.

29 Zdaniem Marksa intensyfikacja pracy dokonuje się poprzez (i) skrócenie czasu pracy, które „opiera się na oczywistym prawie, że zdolność działania siły roboczej pozostaje w stosunku odwrotnym do czasu jej działania. A więc, w obrębie pewnych granic, zyskuje się na stopniu natężenia to, co traci się na długości trwania pracy"; (ii) postęp techniczny i innowacje czasooszczędne powodujące wzrost wydajności. Przywołane już Marksowskie rozróżnienie wielkości ekstensywnej i intensywnej pracy jest odpowiednikiem tego, które stosuje się na gruncie współczesnej neoklasycznej analizy wielkości indywidualnej podaży pracy (intensive margin oraz extensive margin). 
wartości bezwzględnej, której jednostką miary jest praca abstrakcyjna ${ }^{30}$. Przy czym w przypadku Marksa trudno oczywiście mówić o teorii dobrobytu pozytywnego ${ }^{31} \mathrm{w}$ dzisiejszym tego słowa znaczeniu, zwłaszcza w kontekście stawianych przez niego hipotez o zubożeniu czy spadku płac realnych w kapitalizmie. Można jednak zasadnie stwierdzić, że według Marksa (Gintis 1972, 572; zob. także krytykę tego stanowiska: Parsons 1975, 280-290) pracownicy rozwijają się zależnie od sposobu, w jaki partycypuja w społecznych stosunkach produkcji. W takiej sytuacji pewnego rodzaju kryterium indywidualnego rozwoju staje się kryterium odzwierciedlające stopień, w jakim „człowiek realizuje, reguluje i kontroluje” swoja pracę 32 . Tak czy inaczej, teoria wartości bezwzględnej nie jest logicznie związana ani z teoria cen względnych, zgodnie z która jednostką wartości jest ostatecznie ekwiwalent towarów konsumpcyjnych, ani z teorią wartości dodatkowej, głosząca, że praca jest źródłem produktu dodatkowego i wartości dodatkowej i stąd „obiektem” wyzysku.

Wskazanie, że praca stanowi źródło wartości, które tworzy całkowity produkt, stało się fundamentem marksowskiej teorii wartości dodatkowej (i wyzysku), a przez to najczęstszym obiektem ataku przeciwników. Przypomnijmy, że dla Marksa punktem wyjścia było podjęcie rozróżnienia pracy produkcyjnej i pracy nieprodukcyjnej, aby wykazać, że „kapitał” („martwa praca”) nie tworzy żadnej wartości, a jedynie zachowuje ją i przenosi. Wiele lat później Sraffa

30 Współcześnie bowiem dominuje pogląd, zgodnie z którym postulowana przez Marksa teoria wartości dodatkowej (wyzysku) nie wywodzi się bezpośrednio z teorii względnej wartości wymiennej opartej na ilości pracy ucieleśnionej w towarach (z prawa wartości). W świetle takiego poglądu samemu Marksowi miało zależeć nie na udowodnieniu tej pierwszej przez prawo wartości, ale co najwyżej na ich uzgodnieniu (zob. Dobb 1976, 157-158).

31 Można jednak przypisać Marksowi próbę sformułowania szczątkowej teorii dobrobytu negatywnego. Wiadomo bowiem, że jednym z zamiarów Marksa było wykazanie tendencji do względnego zubożenia klasy pracującej. W tym celu za zmienne niezależne (egzogeniczne) przyjął on wartość siły roboczej i tendencję ceny siły roboczej (płac powstających na rynku) do zrównywania z tą pierwszą (o czym mówiła jego teoria płac opartych na wartości siły roboczej). Dla Smitha i Ricarda „uproszczony” wskaźnik dobrobytu społecznego, odbiegający od tego wyrażanego współcześnie w ekonomii dobrobytu w jednostce dochodu realnego, przyjmował postać „,rzeczywistych kosztów” psychofizjologicznych do poniesienia. Dla Marksa kluczowa była rzeczywista wartość, ale zgodnie z tendencją do zubożenia ona sama miała wyrażać się malejąca ilością społecznie niezbędnego czasu pracy koniecznego do wytworzenia „niezbędnych środków utrzymania”. Oznacza to, że dla Marksa ostatecznym standardem wartości miał być standard wartości siły roboczej mierzonej w jednostkach czasu pracy niezbędnego do reprodukcji siły roboczej.

32 W kontekście dobrobytu społecznego istotny jest pogląd Marksa na kwestię struktury własności i demokratycznego podejmowania decyzji w przedsiębiorstwie kapitalistycznym. Pogląd ten różni się od tego, co się obiegowo sądzi, oraz od stanowiska reprezentowanego przez socjalistów utopijnych, postkeynesistów i sraffian. Marks uważał, że tak jak oszczędności robotników muszą prędzej czy później - w wyniku tendencji kapitalizmu do recesji, nadprodukcji i kryzysów - zostać skonsumowane (tutaj Marks jest niekonsekwentny i odmawia możliwości zrealizowania płacy na rozwój siły roboczej), tak „o żądaniu [...] aby dać robotnikom udział w zysku [...] trzeba powiedzieć, że jest to szczególna premia, która tylko jako wyjątek od reguły może osiąnaćc swój cel i faktycznie - jeśli ta praktyka jest w ogóle godna wzmianki - ogranicza się do przekupienia poszczególnych nadzorców itd., jest to praktykowane w interesie pracodawcy przeciw interesom jego klasy; to samo, jeśli chodzi o prowizję itd.; słowem, nie dotyczy to już zwykłego robotnika nie wpływa na ogólny stosunek; albo też jest to osobliwy sposób oszukiwania robotników i zagarniania części ich płacy roboczej w niepewnej formie obietnicy wypłacenia niepewnego zysku, zależnego od stanu interesów” (Marks 1986, 211). 
stwierdza polemicznie, że „nie ma żadnych obiektywnych różnic pomiędzy pracą robotnika najemnego a niewolnika, niewolnika a konia, konia a maszyny, maszyny a elementu natury [...] Koncepcja przypisująca pracy ludzkiej jakiś szczególny dar w określaniu wartości jest czysto mistyczna. Czy kapitalistycznemu przedsiębiorcy, który jest «rzeczywistym podmiotem» kształtowania wartości, robi jakąkolwiek różnicę to, czy zatrudni on człowieka czy zwierzę, niewolnika czy właściciela siły roboczej?”' (Sraffa D3/12/9, 89, cyt. za: Bellofiore 2010, 11-12). Z jednej strony Marks zgodziłby się zapewne [?] ze stwierdzeniem, że nie można jakiejkolwiek rzeczy czy działalności (nie wyłączając pracy) przypisywać żadnych mistycznych cech. Z drugiej zaś strony zarzut Sraffy, że dla Marksa praca ludzka ma jakiś „szczególny dar w określaniu wartości”, wydaje się wiążący jedynie w kontekście teorii wartości względnej. Jednakże w przypadku teorii wartości bezwzględnej (i dodatkowej) zarzut ten przestaje być już oczywisty, zwłaszcza gdy pamięta się, jak wielką wage przywiązywał Marks do poczynionego przez siebie formalnego i materialnego rozróżniania „pracy” i „zdolności do pracy” („siły roboczej”). O tym, jak trudna i wymykająca się uwadze była to operacja analityczna, świadczą liczne komentarze wymierzone przeciw Marksowi, w których adekwatna i przenikliwa krytyka mieszała się z ostrymi atakami. Przy czym należy oddać, że „logika wykładu” Marksa nie ułatwiała czytelnikowi śledzenia jego argumentacji, odwołującej się do przywołanego wcześniej rozróżnienia.

Kontrowersje dotyczące tego, czy kapital jest produkcyjny, czy też nie, mogłyby zostać rozwiązane wraz z rozróżnieniem „tego, co produkcyjne” i „tego, co niezbędne”. Zdaniem Robinson „nie ma znaczenia, czy powiemy, że kapital jest produkcyjny, czy też, że jest on niezbędny po to, by uczynić pracę produkcyjną" (Robinson 1960, 26). Dlatego idea, że tylko twórcza praca „żywa” lub produktywne wydatkowanie siły roboczej są zdolne generować wartość dodatkową staje się dla jednych, w nieunikniony sposób, mało interesującą i krępująca myślenie tautologia, oparta po prostu na definicji „pracy” i „wytwarzania”33, albo po prostu okazuje się ideą fałszywa. Dla innych staje się ona pretekstem do zmiany treści pojęcia pracy i pojęcia wytwarzania. Od kiedy sraffianie (neoricardianie) wykazali, że pojęcie wartości wyrażanej w jednostkach pracy jest na gruncie teorii wartości dodatkowej zbyteczne, prozaiczną kwestią osobistych gustów, lub też ideologicznych wyborów, staje się to, czy wartość dodatkowa będzie określana w godzinach czasu pracy, czy np. w buszlach kukurydzy. Co więcej, jeśli zdolność pracy do wytwarzania wartości dodatkowej miałaby być podstawą twierdzenia o szczególnym statusie pracy, wówczas to twierdzenie musiałoby być niewątpliwie odrzucone (Bowles i Gintis 1985, 34). Nadal jednak można bronić twierdzenia, że samo

33 Sam Marks mianem płaskiej tautologii określił argumentację następującego typu: „Ale czym jest wartość towaru? Przedmiotową formą pracy społecznej wydatkowanej na wytworzenie go. A czym mierzyć wielkość jego wartości? Wielkością zawartej z nim pracy. Cóż więc określałoby wartość np. dwunastogodzinnego dnia roboczego? Dwanaście godzin pracy zawartych w dwunastogodzinnym dniu roboczym” (Marks 1951, 576). 
„posiadanie kapitału nie jest działalnościa produkcyjna” (Robinson 1960, 27), bazując na ogólnym założeniu, że w demokratycznym społeczeństwie chodzi nie o to, co się posiada, lecz raczej o to, co się robi. Poza tym ewentualna zgoda na to, że posiadanie kapitału jest produkcyjne, dostarcza niepotrzebnego argumentu, który raczej zaciemnia problem w sytuacji, gdy w wyniku wewnętrznej dynamiki kapitalizmu w dużej mierze nastapił rozdział własności i prowadzenia przedsiębiorstw, a typowy przedsiębiorca coraz częściej przyjmuje postać rozproszonego akcjonariusza, który nie ma żadnego wpływu na bieżące funkcjonowanie przedsiębiorstwa, w tym na bieżące praktyki wynagradzania i koordynowania pracownic i pracowników.

Problemem, który powstaje po odrzuceniu marksowskiej teorii wartości dodatkowej i w efekcie jego teorii wyzysku, jest status pracy. Okazuje się, że sraffianie - wbrew ich twierdzeniu, że produkcja jest dla nich procesem społecznym, a nie tylko technicznym - nie dostarczaja jakiegokolwiek innego kryterium, na podstawie którego np. można by wyróżnić pracę spośród innych nakładów produkcyjnych (czynników produkcji, ekwiwalentu środków utrzymania). Gdyby przystać na argumentację sraffian (Steedman 1977), wówczas pojawia się niebezpieczeństwo, że Marksowska teoria reprodukcji pracowników za pomocą pracy zostanie przetransponowana w Sraffowską teorię produkcji towarów za pomocą towarów. Wprawdzie sraffianie deklaruja, że odróżniaja pracę od innych towarów i nakładów, lecz w dalszym ciagu zgodnie ze stanowiskiem marksowskim można im zarzucić, że: (i) robią to nie na podstawie quasi-obiektywnych (społecznych, formalno-prawnych, statystycznych) cech, ale w rezultacie sądu wartościującego decydującego o zainteresowaniu się podziałem dochodu narodowego na „kapitał” i „pracę”; (ii) ostatecznie redukuja „pracę” do jednostki „płacy realnej” (środków utrzymania), a pracownika do roli konsumenta, przez co odmawiaja jakiegokolwiek znaczenia kategorii wartości siły roboczej, wyrażonej w jednostkach pracy abstrakcyjnej (lub społecznej). Pojawia się pytanie, czy perspektywa sraffian zapewnia wystarczający warunek, by „upodmiotowić” pracę? Czy odrzucając związek analityczny wartości wyrażanych w jednostkach społecznie niezbędnej pracy abstrakcyjnej ucieleśnionej w towarach i wartości dodatkowej wytwarzanej wyłącznie przez pracę żywa, nie degraduje się analitycznie samej „pracy”? A jeśli tak, to jaki jest konieczny warunek „podmiotowości pracy”, który wykraczałby poza fakt, że siła robocza jest ucieleśniona w istotach ludzkich?

W kolejnych częściach niniejszego artykułu wskazana zostanie pewna ścieżka argumentacji na rzecz pewnej wersji teorii wartości. Rację ma M. Dobb (1937, 20), głosząc, że stwierdzenie, iż praca stanowi jakiś szczególny koszt społeczny, jest kwestia praktyczna, w tym sensie, że o jej rozstrzygnięciu decyduje raczej sąd wartościujący badacza aniżeli reguły logiczne. Kiedy już dany badacz decyduje się prowadzić dociekania gospodarki kapitalistycznej na gruncie zasady pracy - kontynuuje $\operatorname{Dobb}(1937,21)$ - oznacza to nie tylko stosowanie jakiegoś formalnego pojęcia: oznacza to raczej wydanie istotnego stwierdzenia jakościowego, 
dotyczącego natury problemu ekonomicznego (stwierdzenia jakościowego, które jest często mylone z oceną etyczna), co pociaga za sobą skutki dla wyników prowadzonych dociekań. Oznacza to, że obrona klasycznej marksowskiej teorii wartości jako teorii cen względnych ${ }^{34}$ lub jako teorii wartości dodatkowej (i wyzysku) ${ }^{35}$ może okazać się bezzasadna. Jeśli przedstawiona argumentacja jest poprawna, to wspomniana ścieżka, którą można pójść, jest rekonstrukcja teorii wartości bezwzględnej, mierzonej za pomoca pracy abstrakcyjnej i, mimo wszystko, krytyczne odczytanie marksowskiej teorii wartości siły roboczej opartej na pracy niezbędnej. Takie zamierzenie oznacza jednak odejście od rozumienia pracy w kategoriach (i) „mistycznego” źródła produktu i wartości dodatkowej oraz (ii) „uprzedmiotawiającego (zreifikowanego)"36 czynnika (nakładu) produkcji, i skupienie się na jej rozumieniu

34 Zwłaszcza w sytuacji, gdy dobrze rozpoznane zostały niedoskonałości mechanizmu rynkowego w postaci asymetrii informacji, problemu selekcji negatywnej itp.

35 Zwłaszcza w sytuacji, kiedy popularność zdobywają też inne teorie wyzysku oparte na niedoskonałościach mechanizmu rynku, a marksowska propozycja w swej klasycznej postaci jest analitycznie nieczuła na ewentualne przypadki wyzysku jednej grupy pracowników najemnych przez druga.

36 Nie chodzi o to, że samo „uprzedmiotawiające” pojęcie pracy jest niepoprawne z jakiegoś etycznego czy aksjologicznego punktu widzenia. Rację mają Bowles i Gintis, stwierdzając, że „praca nie jest z natury nudna, opresyjna czy ograniczająca. Ani też nie jest z natury ekscytująca i wyzwalająca. [Praca] nie jest „z natury” jakakolwiek. To, jaka jest praca - nasze doświadczanie jej i nasze na nią reagowanie - zależy w znaczącym stopniu od tego, jak zorganizowany jest proces pracy, jak zorganizowana jest reszta społeczeństwa oraz od naszego dopasowania w procesie pracy” (Bowles et al. 2005, 285). Wszelkie „dramatyzowanie” pracy wpisuje się tylko w tendencję, która nie pozwala uwolnić się od krępującego myślenie sporu o substancję pracy. Tutaj chodzi raczej o konsekwencje przejęcia takiego, a nie innego pojęcia pracy, o kryjąca się za tym motywację oraz o cel, jaki chce się przez to osiagnąć. „Przedmiotowe” pojęcie pracy charakteryzuje się tym, że praca w sensie ludzkiej pozytywnej działalności niewiele różni się od innych nakładów, a jeśli już, to raczej „empirycznie” lub w wyniku sądu moralnego. W takiej sytuacji samo rozróżnienie pracy i siły roboczej - fundamentalne dla podmiotowego ujęcia - ma znaczenie tylko i wyłącznie jako proste narzędzie translacji kategorii z jednego słownika pojęciowego na inny słownik, jako narzędzie transponowania jednego systemu pomiaru na drugi, jednej miary w postaci godziny na inną w postaci faktycznej pracy. Rozróżnienie siły roboczej i pracy staje się więc kwestią matematycznej i statystycznej techniki wyrażenia wielkości faktycznej pracy w kategoriach danej wielokrotności ilości godzin, na które zostało się wynajętym. Metodologiczne konsekwencje zastosowania takiego „przedmiotowego” pojęcia pracy okazują się dalekosiężne. Wystarczy zrekonstruować cztery najważniejsze: (i) przyjmuje się, że konkurencja wymusza na przedsiębiorcach efektywne wykorzystywanie technologii i metod organizacji. Wówczas jakakolwiek zmiana stosunków własności lub podejmowania decyzji w firmie nie spowoduje ani zmian technologicznych, ani organizacyjnych, chyba że zmieni także ceny względne nakładów produkcyjnych i produktu końcowego. $Z$ tego wynika, że demokratyzacja firm może zmienić podział dochodów w firmie, lecz wyłącznie kosztem mniejszej wydajności. Taka argumentacja stanowi wyprzedzenie i odrzucenie wszelkiej krytyki dominacji, rutyny i zaniku umiejętności, fragmentaryzacji życia zawodowego itp. W analizie kapitalistycznej gospodarki rynkowej: (ii) przyjmuje się, że przedsiębiorcy wynajmuja siłę roboczą, tak jak każdy inny towar, po najniższej akceptowalnej stawce płacy za godzinę. Wówczas, przy założeniu zbliżonych zdolności produkcyjnych, preferując np. zatrudnianie kobiet, a nie mężczyzn, sprawią, że płace tych ostatnich będą wyższe, a ci, którzy dyskryminują kobiety i upierają się przy zatrudnianiu „droższych” mężczyzn, zostaną niechybnie wyeliminowani przez konkurencję. Z tego wynika, że wszelka dyskryminacja zniknie jako naturalny rezultat konkurencyjnego poszukiwania przez kapitalistów źródeł zysku; (iii) przyjmuje się, że każda niesprzedana (niewynajęta) jednostka pracy stanowi jednostkę „dobrowolnie” wycofaną z rynku, gdyż nadwyżkę podaży można wyeliminować tylko wtedy, gdy sprzedawca przyjmie niższa płacę. Bezrobocie dobrowolne oparte na odmowie pracy po niższej płacy to w myśl takiego stanowiska forma spekulacji swoimi własnymi zdolnościami produkcyjnymi i najlepiej byłoby, gdyby taka forma spekulacji była zakazana i wprowadzony został nakaz pracy. Z tego wynika, że bezrobocie nie jest ani marnotrawstwem zasobów, ani znaczącym problemem społecznym. (Bowles i Gintis 1985, 35-36); (iv) Przyjmuje się, że funkcja użyteczności każdego pracownika redukuje go do mechanizmu optymalizującego 
w kategoriach (iii) „normalnego” miernika wartości bezwzględnej. Takie podejście wymaga zmierzenia się z marksowskim pojęciem pracy abstrakcyjnej, równie kłopotliwym i otoczonym nie mniejszą aurą tajemniczości. Liczne kontrowersje wokół tego pojęcia mogą dziwić, gdyż Marks jasno i precyzyjnie wskazał na jednostkę pracy abstrakcyjnej (pracy w ogóle, jednorodnej pracy ludzkiej) w postaci „,czasu pracy potrzebnego do wytworzenia jakiejś wartości użytkowej $\mathrm{w}$ istniejących społecznie normalnych warunkach produkcji i przy społecznie niezbędnym stopniu umiejętności i intensywności pracy”37 (Marks 1951, 41).

\section{Problem pracy i jej pomiaru}

Przyjmuje się, że specyfika ekonomii marksowskiej polega na szczególnym sposobie reprezentacji pracy, który z jednej strony czyni ją fenomenem innego rodzaju względem pozostałych nakładów produkcyjnych i w wyniku tego za nieuzasadnione uznaje się każdy przypadek redukcji pracy do jednego z technicznych czynników produkcji lub do innych towarów konsumpcyjnych (artykułów płacowych), będących środkami utrzymania, niezbędnymi do wytworzenia, zachowania i rozwoju siły roboczej. Interesująca kwestia jest tutaj to, o jak rozumiana „pracę” chodzi? Dlatego też w pierwszej kolejności należałoby rozstrzygnać, czy chodzi o pracę w sensie przykrego wysiłku, praktykowania umiejętności, wydatkowania siły roboczej, twórczej ekspresji czy może jakąś kompilację tych idei? Wszystkie te określenia pracy nie dotyczą tylko i wyłącznie subiektywnego stosunku człowieka do swej własnej działalności, lecz raczej odnoszą się do sposobu użycia swych zdolności do pracy (siły roboczej), który jest wytworem społecznych stosunków produkcji. W następnym kroku trzeba

stosunek krańcowej użyteczności dochodu i krańcowej przykrości pracy. W myśl tej zasady pracownik zabiega wyłącznie o wielkość poniesionego przez siebie nakładu [czasu] pracy, w ogóle nie będąc zainteresowanym krótkookresowymi wariacjami stopnia realizacji faktycznej pracy oraz kwestiami zwiazanymi z trybem i warunkami pracy. Co więcej, przedstawia się pracownika jako jednostkę obojętną wobec różnych sposobów bezpośredniego zastosowania jego osobistej siły roboczej, tak iż ma on nie zwracać w ogóle uwagi na sposób, w jaki faktycznie wykonuje swoja pracę, czy też na sposób alokacji jego faktycznej pracy do różnych zadań. Twierdzenie, iż wyizolowana jednostka skupia się wyłącznie na minimalizowaniu ilości nakładów [czasu] pracy i maksymalizowaniu wysokości płacy realnej miało swoje konsekwencje, spośród których istotne były m.in. zignorowanie oczywistego związku pomiędzy jakością (trybem) wykonywania faktycznej pracy a dobrobytem pracownika oraz odmówienie efektywności firmom, które nie byłyby hierarchicznie zorganizowane. Widać zatem, że przyjęcie „przedmiotowego" pojęcia pracy implikuje wiele problemów. Jeśli nie dostrzega się problemu $\mathrm{w}$ formalnym definiowaniu pracy w kategoriach przedmiotowych, to przynajmniej należy zwrócić uwage na konsekwencje teoretyczne i praktyczne, jakie niesie ze sobą takie stanowisko. Argument (i) można określić mianem „niedemokratyczności”, (ii) „niesprawiedliwości”, (iii) marnotrawstwa (nieoptymalne zatrudnienia), (iv) ,konsumpcjonizmu” (zob. K. Nowak 2011, 157-166, 191-192).

37 Pojęcie pracy abstrakcyjnej jako działalności charakterystycznej tylko i wyłącznie do rozwiniętej gospodarki kapitalistycznej, w ramach której jedynym źródłem utrzymania części społeczeństwa jest wymiana za pośrednictwem rynku usług siły roboczej za płacę robocza, zostało zarezerwowane przez Marksa wyłącznie do działalności ludzkiej. Dlatego uprzedził on "posthumanistycznego” czytelnika, że w swej krytyce ekonomii politycznej „,nie będziemy rozpatrywać pierwszych, po zwierzęcemu jeszcze instynktownych postaci pracy” (Marks 1951, 188-189). 
odpowiedzieć na pytanie dotyczące wyboru odpowiedniej i kompatybilnej z przyjęta już koncepcją wartości oraz pracy jednostki miary dla pracy.

Spór o pojęcie pracy ma długą i niezwykle barwną tradycję, w której wykrystalizowało się kilka normatywnych modeli pracy: (i) model przykrości pracy, zgodnie z którym praca to poświęcenie i nakład przykrego wysiłku; (ii) ascetyczny model pracy, zgodnie z którym praca to energiczne ćwiczenie i praktykowanie umiejętności; (iii) model abstrakcyjnego charakteru pracy, zgodnie z którym praca to „normalna czynność życiowa” i normalne wydatkowanie ludzkiej siły roboczej; (iv) ekspresywistyczny model pracy, zgodnie z którym praca to twórcza ekspresja zapewniająca samorealizację. Moment przesilenia w tym sporze przyszedł wraz z narodzinami klasycznej ekonomii politycznej, na gruncie której spotkały się różne idee pracy oraz różne procedury pomiaru wartości i pracy.

Przypomnijmy, że w marksowskiej definicjii ${ }^{38}$, odnoszącej się do propozycji z zakresu klasycznej ekonomii politycznej, „praca” to nie tyle twórcza ekspresja czy nieprzyjemny wysiłek i „ofiara ze spoczynku, wolności i szczęścia” (Marks 1951, 50) - jak chciał tego Smith, a nawet Ricardo - ile „normalna czynność życiowa” (Marks 1951, 50), „produkcyjne użytkowanie ludzkiego mózgu, mięśni, nerwów i rąk” (Marks 1951, 47), ,abstrakcyjna praca ludzka”, gdzie „człowiek «przy zwykłym stanie swego zdrowia, sił i usposobienia, zwykłym stopniu swej umiejętności i sprawności» ma potrzebę normalnej ilości pracy. Co prawda, sama miara pracy jest dana z zewnątrz, przez cel, który trzeba osiagnać, i przez trudności, które trzeba pokonać pracą dla jego osiagnnięcia. Ale tego, że pokonywanie trudności jest samo przez się urzeczywistnieniem wolności i że, dalej, zewnętrzne cele tracą pozór narzucanej z zewnątrz przyrodniczej konieczności i stają się celami, które dopiero indywiduum sobie stawia - a więc samourzeczywistnienia, uprzedmiotowienia podmiotu, a zatem rzeczywistej wolności, której akcją jest właśnie praca - tego wszystkiego Smith się także nie domyśla" (Marks 1986, 491). Zdaniem Marksa „ze Smithowskiej koncepcji ofiary, która słusznie zresztą wyraża subiektywny stosunek robotnika najemnego do swej własnej działalności, nie wynika to, czego chce Smith - mianowicie określenie wartości czasem pracy" (Marks 1986, 493). Ostatnie zdanie może wprawiać w zakłopotanie niektórych marksowskich kontynuatorów, upatrujących w pracy twórczej ekspresji, gdyż Marks dopuszcza w nim możliwość negatywnego psychologicznie stosunku robotnika do swej aktywności produkcyjnej. Gdyby wykluczyć tutaj wyłącznie jednorazowe niedopatrzenie, kurtuazyjny ukłon w stronę swego uznanego poprzednika lub ujęcie w ten sposób własnej koncepcji alienacji, wówczas uwagę Marksa należy rozumieć jako wyraz metodologicznej świadomości tego, że sądy wartościujące mogą być oparte między innymi

38 W przypadku koncepcji Marksa pewne wątpliwości mogą budzić następujące kwestie: (i) do jakiej idei pracy odwoływał się w istocie Marks i czy była to zawsze i wszędzie ta sama idea; (ii) jaka była jednostka miary pracy (jak rozumieć społecznie niezbędną godzinę pracy?), (iii) wreszcie, czy pojęcie i jednostka miary były przez niego stosowane konsekwentnie i spójnie? 
na alternatywnych założeniach, które pretendują do opisu rzeczywistości pracy (np. uczucie przykrości pracy, świadomość partycypacji, poczucie doskonalenia się, alienacja itp.). Wtedy dopuszczalność opisowego stwierdzenia może bardzo znaczaco wpływać na nasze sądy wartościujące, a co za tym idzie, na charakter propozycji teoretycznej, treść pojęcia pracy oraz jednostkę jej pomiaru. Dlatego w teorii ekonomii - jak miał powtarzać często Sraffa - wnioski są nierzadko mniej istotne niż sposób, w jaki się do nich doszło.

Według Marksa można wygenerować, z jednej strony, miernik pracy niższego rzędu, który wyrażałby „cel, który trzeba osiagnacć” i byłby nim wówczas stosunek społecznie niezbędnego czasu pracy do produktu końcowego, z drugiej zaś miernik pracy wyższego rzędu, wyrażający „trudności, które trzeba pokonać praca, by osiągnać zamierzony cel”, a byłby nim wtedy stosunek pracownika do własnej siły roboczej i warunków pracy. Oczywiście, Marks nie ma tutaj na myśli „trudności” w sensie subiektywnej przykrości, ponieważ ta ostatnia, wyrażona w języku analizy marginalnej, wiąże się z koniecznością natychmiastowego motywowania pracownika do pracy za pomoca zachęt finansowych albo groźby zwolnienia w sytuacji krańcowej, kiedy subiektywnie odczuwana przykrość zrównuje się z użytecznością czerpaną z jednostki dochodu. Zdaje się, że Marks rozumie „trudności”, przed jakimi staje pracownik, w kategoriach wyzwania (problemu). Dzięki uporaniu się z tym wyzwaniem (rozwiązaniu problemu) pracownik doskonali (learning by doing) swoją zdolność do pracy (siłę robocza).

Jak wynika z powyższego, Marks zdystansował się wobec tradycji, która „podchodzi do pracy psychologicznie, od strony przyjemności czy przykrości, jaką ona sprawia człowiekowi, [gdyż] oprócz tego uczuciowego stosunku człowieka do swej działalności praca jest przecież jeszcze czymś innym - po pierwsze, dla innych, gdyż samo poświęcenie ze strony A nie przyniesie żadnego pożytku B; po wtóre, praca jest określonym stosunkiem samego człowieka wobec rzeczy, którą obrabia, i wobec jego własnych zdolności do pracy. Praca jest pozytywną, twórczą działalnością. Miara pracy - czas - nie zależy oczywiście od jej produkcyjności; jej miara jest niczym innym jak jednostka, której określona ilość wyraża określone wielkości pracy. Z tego pewnością nie wynika, że wartość pracy jest stała; chyba tylko w tym sensie, że jednakowe ilości pracy stanowią jednakowe mierniki” (Marks 1986, 493).

Pierwsza kontrowersja między Marksem a pozostałymi ekonomistami politycznymi dotyczyła tego, czy można „dowieść analitycznie, czy ekonomiczne pojęcie pracy da się w ogóle rozszerzyć do koncepcji twórczej i zarazem kształtującej wytwórczości” (Habermas 1987, 201), przy czym warunkiem wystarczającym jej uwolnienia jest zmiana stosunków produkcji, czy raczej należy je zredukować do koncepcji przykrego i zarazem instrumentalnego wysiłku, przy czym warunkiem niezbędnym jego wydatkowania jest motywacja w postaci płacy, a może trzeba wznieść się ponad ten spór i sformułować ogólniejszą koncepcję ekonomicznego pojęcia pracy, przy czym warunkiem byłoby „to, co normalne”? Druga kontrowersja odnosiła się do 
kwestii wyboru i uzasadnienia najbardziej adekwatnej jednostki miary dla nakładu pracy ${ }^{39}$ w procesie produkcji, która to jednostka stanowiłaby również miernik wartości bezwzględnej. Należy w tym miejscu zasygnalizować, że z tego samego powodu, z jakiego teoria ekonomii głównego nurtu boryka się z trudnościami dotyczącymi ustalenia: (i) związku pomiędzy rzeczywistą godzina pracy a „rzeczywistymi, psychologicznymi kosztami” (przykrościa pracy) oraz (ii) związku pomiędzy rzeczywista godzina pracy a wielkością produktu końcowego, także i marksowska ekonomia nie może być wolna od podobnych kłopotów. Wydaje się, że w jej przypadku mogą istnieć nawet większe trudności, gdyż należałoby wskazać: (i) związek nie między rzeczywistą godzina pracy, ale między społecznie niezbędną godziną pracy a wielkością produktu końcowego, oraz (ii) związek pomiędzy społecznie niezbędna godzina pracy a learning by doing i przeciętna intensywnościa pracy (zob. Arrow 1962, 155-173; w kwestii znaczenia „uczenia się przez praktykę” dla ekonomii marksowskiej, zob. Tregenna 2009).

Kiedy okazało się, że w swojej teorii wartości opartej na pracy Smith wyszedł z idei przykrości, kontrowersje wokół pracy rozgorzały na nowo. Klasycy ekonomii politycznej zmuszeni byli poczynić założenie o homogeniczności pracy, przy czym uzasadniano je, odwołując się w ostatniej instancji do różnych idei pracy oraz różnych jednostek pomiaru i jednostek komparatystycznych. Wychodząc z idei przykrości, Smith przyjął uniwersalną jednostkę przykrości wysiłku (rzeczywisty subiektywny koszt psychologiczny). Ricardo za takową uznał powszechne minimalizowanie wysiłku na jednostkę produktu w danym czasie. Natomiast Marks - wychodzący z idei pracy abstrakcyjnej - za taka jednostkę uznał czas pracy społecznie niezbędny, „czyli czas pracy potrzebny do wytworzenia jakiejś wartości użytkowej $\mathrm{w}$ istniejących społecznie normalnych warunkach produkcji i przy społecznie niezbędnym stopniu umiejętności i intensywności pracy” panującym w danym momencie czasu. Co więcej, jak pamiętamy, dla Marksa „oprócz [...] uczuciowego stosunku człowieka do swej działalności

39 We współczesnej teorii ekonomii oraz statystyki gospodarczej „konkurują ze sobą” dwa podejścia do pomiaru nakładu pracy: pierwszym jest pomiar w jednostkach ,ilości zatrudnionych”, a drugim jest pomiar w jednostkach „osobogodzin” („roboczogodzin”). Dostrzega się też, iż wybór techniki pomiaru nakładu pracy nie może być w pełni niezależny zarówno od procedury i rezultatu pomiaru wyniku (wytworzonego produktu końcowego), jak i od powziętego stanowiska odnośnie do znaczenia zmian wydajności. Jednostki, w jakich mierzy się nakład pracy i które mogą być dalej dostępne w praktyce porównywania sytuacji w różnych okresach czasu, można zredukować do (i) przeciętnej liczby osób zatrudnionych oraz do (ii) całkowitej liczby przepracowanych godzin. Oczywiście w praktyce istnieje wiele wariantów obu jednostek. Sensowny wybór, czy nawet dyskusja wymagają dysponowania informacjami dotyczącymi dwóch aspektów „godzin pracy”, o których teoria ekonomii i statystyka ekonomiczna wciąż wiedzą bardzo mało. Pierwszy dotyczy tego, jaki jest związek pomiędzy godzinami pracy i subiektywnymi „rzeczywistymi (psychologicznymi) kosztami” - „przykrością” - pracy, drugi zaś tego, jaki jest związek pomiędzy godzinami pracy i produktem końcowym. Ponadto w dalszym ciągu niewiele wiadomo na temat tego, czy to zmiana wielkości całkowitych przepracowanych osobogodzinach, czy też wielkości zatrudnienia, stanowi lepsze przybliżenie zmian w rzeczywistych kosztach psychologicznych, czyli przykrości pracy. Problemem pozostaje jednak to, że wciąż nie do końca wiadomo, o którym stopniu (rzędzie) przybliżenia mowa, gdy chodzi o dwie wskazane wcześniej relacje. Jeśli stanowią „drugie przybliżenie”, to czy w trakcie jego realizacji nie utracono istotnych informacji dostępnych w „pierwszym przybliżeniu”? Czy kiedykolwiek podjęto próbę porównania rezultatów, do jakich dochodzi się, zakładając istnienie „przykrości pracy” i nie czyniąc tego założenia bądź czyniąc założenie o „radości z pracy”? (zob. Denison 1961, 347-386). 
praca jest przecież jeszcze czymś innym - po pierwsze, dla innych, gdyż samo poświęcenie ze strony A nie przyniesie żadnego pożytku B; po wtóre, praca jest określonym stosunkiem samego człowieka wobec rzeczy, którą obrabia, i wobec jego własnych zdolności do pracy. Praca jest pozytywna, twórczą działalnością" (Marks 1986, 493), nastawioną na wytwarzanie wartości użytkowych. „Naturalna ceną rzeczy nie jest poniesiona dla niej ofiara [...] Musi być jeszcze poza ofiarą coś innego. Tak jak można mówić o poświęceniu spoczynku, tak samo można coś nazwać poświęceniem lenistwa, braku wolności, nieszczęścia, czyli wyrazić negację stanu negatywnego" (Marks 1986, 493). W ten sposób Marks poszukuje miary dla stosunku człowieka do wartości użytkowej, którą on kształtuje, a przez to do swej własnej siły roboczej. A zatem problem wartości bezwzględnej i „dobrobytu” u Marksa dotyczyłby problemu „społecznego zapośredniczenia, dzięki któremu indywiduum odnosi się [w określony sposób] do środków swojej reprodukcji i dzięki któremu je wytwarza, a więc dotyczy warunków produkcji i stosunku indywiduum do tych warunków” (Marks 1986, 487).

Można więc naszkicować marksowską teorię wartości bezwzględnej mierzonej za pomoca pracy, lecz trzeba przy tym pamiętać, że Marks przestrzegał, by w ramach opisywania rzeczywistości z perspektywy uprawnień pracowników zachować ostrożność, gdyż, jego zdaniem, prawa oparte na pracy leżą wewnątrz „,wąskiego horyzontu praw burżuazyjnych” 40 (Marks i Engels 1949, 15) i wynikają z ujęcia, według którego osoby „są traktowane wyłącznie jako robotnicy i nie dostrzega się w nich nic innego, wszystko inne jest ignorowane" (Marks i Engels 1949, 15). Każde równe prawo, zgodnie z którym następuje podział „przedmiotów osobistego spożycia” (Marks i Engels 1949, 14) oznaczać może tylko tyle, że „wymienia się określoną ilość pracy w jednej postaci na takąż ilość pracy w postaci innej” (Marks i Engels 1949, 15) i, jako takie, wciąż pozostaje „prawem burżuazyjnym”. Z racji tego, że ludzie różnią się pod względem fizycznym i umysłowym, praca nie może występować jako „źródło

40 Co więcej, zdaniem Marksa „można powiedzieć, że w wymianie między robotnikiem a kapitałem dla robotnika celem wymiany, a zatem i produktem tej wymiany, są nie środki utrzymania, lecz bogactwo [pieniężne], nie poszczególna wartość użytkowa, lecz wartość wymienna jako taka [...] robotnik mógłby w większym stopniu wyrzec się wypoczynku, mógłby w ogóle wyrzec się swego istnienia na rzecz istnienia jako robotnika, pozostając tylko robotnikiem, odnawiając więc częściej akt wymiany lub rozszerzając go ilościowo - słowem - przez pilność. Dlatego również w dzisiejszym społeczeństwie żąda się pilności - a zwłaszcza oszczędzania, wyrzeczenia - nie od kapitalistów, lecz od robotników, przy czym żądania te wysuwają mianowicie kapitaliści. Obecne społeczeństwo stawia paradoksalne żądanie wyrzeczeń temu, dla kogo przedmiotem wymiany sa środki utrzymania, nie zaś temu, dla kogo celem wymiany jest wzbogacenie się (Marks 1986, 208-209). Jak dodaje Marks, ,gdyby robotnicy powszechnie [...] spełnili te żądania [...] to musiałoby to doprowadzić ich wprost do $[\ldots]$ poziomu takiego robotnika najemnego, dla którego jedyny przedmiot i cel wymiany z kapitałem stanowi zwierzęce minimum potrzeb, środków utrzymania. Stawiając sobie za cel bogactwo [pieniężne] zamiast wartości użytkowych, robotnik nie tylko nie doszedłby więc do żadnego bogactwa, lecz na dodatek utraciłby jeszcze wartość użytkowa. Z reguły bowiem maksimum pilności, pracy i minimum konsumpcji - a do tego wiedzie maksimum jego wyrzeczeń i jego pogoń za pieniądzem - doprowadziłaby tylko do tego, że otrzymywałby minimum płacy za maksimum pracy. Wytężając się, obniżyłby tylko ogólny poziom kosztów produkcji swej własnej pracy, a zatem jej ogólną cenę [...]. Jeżeli wszyscy robotnicy - lub ich większość - są nadmiernie pilni [...] to nie powiększają wartości swego towaru, lecz tylko jego ilość, a więc zwiększają wymagania stawiane im jako wartości użytkowej (Marks 1986, 209). 
wszelkiego bogactwa [w postaci wartości użytkowych] i wszelkiej kultury”, lecz może „służyć jako miara, musi być określona pod względem rozciąłości albo intensywności, w przeciwnym bowiem razie przestaje być miernikiem. To równe prawo jest nierównym prawem dla nierównej pracy. Nie uznaje ono żadnych różnic klasowych, gdyż każdy jest tylko robotnikiem jak inni; ale uznaje milcząco nierówne osobiste uzdolnienia, a zatem i nierówną zdolność do pracy, jako przywileje naturalne" (Marks i Engels 1949, 15) . Nie powinno dziwić, że wychodząc z takich założeń, Marks był zmuszony odrzucić postulat, iż „nieokrojony dochód z pracy należy na równych prawach do wszystkich członków społeczeństwa” (Marks i Engels 1949, 12), gdyż dla niego w tym kontekście „praca” nie jest ani przyczyną wartości względnej, ani źródłem wartości dodatkowej, lecz tylko miernikiem wartości bezwzględnej (indywidualnego dobrobytu). Wówczas równe prawo to nic innego jak „zastosowanie równego miernika”41.

Jedną z najważniejszych możliwości zastosowania równego miernika w celu porównania sytuacji materialnej pracowników jest pewna szczególna wartość użytkowa, w pewien szczególny sposób „konsumowana” w gospodarce kapitalistycznej, mianowicie „siła robocza” („,zdolność do pracy”). O ile o zwykłych towarach konsumpcyjnych i zwykłych nakładach produkcyjnych można powiedzieć, że ich produkcja ma w całej rozciagłości miejsce w obrębie kapitalistycznego procesu produkcji, o tyle tego warunku nie spełnia przypadek „osobliwego, szczególnego towaru”, jakim jest zdolność do pracy.

Tak więc, jeśli chce się bronić LTV, to jedną z możliwości jest wykorzystanie argumentu dotyczącego nie-towarowego aspektu zdolności do pracy i nie-konsumpcyjnego kontekstu realizowania pracy. Po pierwsze, oznacza to, iż „przez siłę robocza lub zdolność do pracy rozumiemy całokształt uzdolnień fizycznych i duchowych, istniejących w organizmie, w żywej osobowości człowieka, i uruchamianych przezeń przy wytwarzaniu jakichkolwiek wartości użytkowych” (Marks 1951, 177) W samej definicji nie ma niczego, co sugerowałoby, iż siła robocza jest zwykłym, szczególnym, osobliwym, czy nawet quasi-towarem. To wyłącznie decyzją sądu wartościującego można „uzdolnienia fizyczne i duchowe” sprowadzić do towaru, a stosunek człowieka do własnej siły roboczej zinterpretować jako stosunek do towaru. Wobec tego możliwy jest alternatywny sąd wartościujący, w wyniku którego „uzdolnienia fizyczne i duchowe" potraktuje się raczej w kategoriach potencjału, a wówczas stosunek człowieka do własnych zdolności do pracy można zinterpretować jako stosunek do swego potencjału. W takiej sytuacji siła robocza, a raczej zdolność do pracy w ogóle, nie jest towarem, a teoretycznie konieczny i wystarczający argument za nie-towarowym aspektem zdolności do pracy tkwi w rekonstrukcji odmiennego „ustrukturyzowania” procesu produkcji i reprodukcji siły roboczej,

41 Pomija się w tym miejscu Marksowskie (raczej słabo uzasadnione) przekonanie, że w społeczeństwie komunistycznym miał nastąpić zanik różnic między pracą fizyczną i umysłową, a sama praca miała stać się nie tylko źródłem utrzymania, ale również „najważniejszą potrzebą życiową” w społeczeństwie rządzonym zasadą „każdy według swych zdolności, każdemu według jego potrzeb”. 
który występuje nie tylko w systemie kapitalistycznej wymiany i produkcji (rynek, przedsiębiorstwo), ale także w administrowanym przez państwo systemie kształcenia (szkoła) oraz regulowanym kulturowo [i prawnie] systemie socjalizacji (rodzina). Po drugie, oznacza to odejście od stosowanej często przez Marksa definicji pracy jako „wartości użytkowej siły roboczej dla kapitału”, gdyż taka definicja przysłania fundamentalne rozróżnienie szczególnego charakteru wartości użytkowej wytwarzanej przez produkcyjne nakłady ucieleśnione w ludziach zdolnych do praktyki społecznej i wartości użytkowych, które tkwią we wszystkich pozostałych nakładach. Wprawdzie posiadanie tych ostatnich jest wystarczające, by zabezpieczyć „konsumpcję” usług produkcyjnych siły roboczej (Bowles i Gintis 1981, 7-8), lecz nie jest konieczne, by „konsumować” siłę robocza. Oczywiście, krytyka takich definicji nie oznacza, że praca nie jest w rzeczywistości „,wartością użytkową siły roboczej dla kapitału”. Chodzi jednak o to, aby wskazać na konsekwencje, jakie wypływaja z „konsumpcyjnej” interpretacji pracy i ,towarowej” definicji siły roboczej. Jedna z takich konsekwencji to - w odniesieniu do teorii reprodukcji pracowników za pomocą pracy - przyjęcie analitycznej perspektywy charakterystycznej dla języka kapitału oraz naturalizacja i rozciąnięcie jego logiki na obszary funkcjonujące dotąd na gruncie innych pozarynkowych stosunków i mechanizmów. Druga konsekwencja jest mimowolne przyjęcie perspektywy neoklasycznej koncepcji użyteczności i konsumpcji, zgodnie z którą to konsument decyduje ostatecznie o tym, co, jak i w jakich ilościach produkować. A przecież doskonale wiadomo, że przyjęcie tych perspektyw kłóciłoby się z przekonaniem, że to „produkcja” stanowi naczelną zasadę ruchu kapitalizmu, co znalazło swój wyraz w teorii wartości opartej na pracy.

Czy zatem możliwa jest niepesymistyczna rekonstrukcja teorii reprodukcji pracowników za pomoca pracy, wymykająca się logice kapitału, której punktem wyjścia byłaby „produkcja” i jednostka pracy odrzucająca ideę przykrości? Odpowiedź na takie pytanie może, pod pewnymi warunkami, okazać się pozytywna. Jednakże w realizacji takiego zamierzenia na niewiele się zda definicja głosząca, iż „praca jest przede wszystkim procesem zachodzącym między człowiekiem a przyroda, procesem, w którym człowiek poprzez swoją działalność realizuje, reguluje i kontroluje wymianę materii z przyrodą" (Marks 1951, 188). Taka definicja zdaje się ahistoryczna, a poza tym zawiera metafory psychofizjologiczne, co może utrudniać jakiekolwiek jej korekty. Nie jest też w stanie uchwycić szczególnego charakteru pracy najemnej, ponieważ na pierwszy plan wysuwa fizyczne przywłaszczania sobie przez człowieka przyrody, zwykłą manipulację przedmiotami fizycznymi, działanie instrumentalne dotyczące stosunku człowieka do rzeczy. Taka koncepcja rzeczywiście może nasuwać podejrzenie o wykluczenie różnych rodzajów „działalności niematerialnej”, które - same stanowiąc źródło utrzymania i środek zatrudnienia - sa przecież nie tylko niezbędne do generowania zysków (usługi finansowe, kapitał finansowy itp.), jak zapewnia teoria kapitału, ale także niezbędne do reprodukowania wartości użytkowej siły roboczej i społeczeństwa, co wydaje się postulować 
teoria pracy. W związku z tym, nawet jeśli przywołana wcześniej definicja byłaby tylko i wyłącznie idealizującym założeniem bądź pierwszym przybliżeniem, to w najlepszym wypadku należałoby je uznać za niefortunne i jak najszybciej nie tyle uchylić jej elementy, ile z uwagi na konsekwencje wynikające z jego zastosowania - zastąpić innym, mianowicie takim, jaki nie traci $z$ oczu tego aspektu pracy najemnej, który polega na trojakim stosunku: (i) pracownika do jego własnych zdolności do pracy (learning by doing, Bildung); (ii) pracownika do społecznych stosunków produkcji, które reprodukują jego siłę robocza; oraz (iii) pracownika do innych pracowników. Wobec tego należałoby raczej punktem wyjścia uczynić pojęcie pracy odwołujące się do pracy niezbędnej i wystarczającej do reprodukcji normalnego stanu rzeczy, którego podtrzymaniem lub zmianą zainteresowany jest pracownik. Oczywiście wymaga to sprecyzowania „tego, co wystarczające”, „tego, co niezbędne” i „tego, co normalne”. Wskazówką niech będą tutaj uwagi Marksa, według którego praca to „normalna czynność życiowa” (Marks 1951, 50), gdzie „,człowiek «przy zwykłym stanie swego zdrowia, sił i usposobienia, zwykłym stopniu swej umiejętności i sprawności» ma potrzebę normalnej ilości pracy” (Marks 1986, 491), która zakłada „przeciętną miarę wprawy, wyszkolenia i szybkości” (Marks 1951, 208).

Co więcej, nie do utrzymania wydaje się też koncepcja sprowadzająca „siłę roboczą” do towaru, jakkolwiek byłby on „osobliwy”, „szczególny” czy „wyjątkowy”. Na poparcie można przytoczyć następująca argumentację. Zdaniem Marksa towary wytwarzane są wyłącznie przez pracę abstrakcyjna. Okazuje się jednak, że siła robocza nie jest tak wytwarzana, stąd można wnosić, że siła robocza nie jest towarem. Siła robocza jest wytwarzana nie tylko przez pracę abstrakcyjną (której alokacją rządzi rynek), ale również przez pracę społeczną, którą rządzi społeczny podział pracy. Zdaje się, że nieuzasadnione sprowadzenie pracy społecznej do pracy abstrakcyjnej wprowadziło sporo zamieszania do marksowskiej teorii wartości (produkcji i reprodukcji) siły roboczej² ${ }^{42}$ Tym różni się produkcja i reprodukcja szczególnego przypadku, jakim jest siła robocza, iż - jak stwierdził Lange - gdy „płace wzrosna powyżej ceny naturalnej siły roboczej, tak że grozi to zniknięciem zysków pracodawcy, nie ma żadnej możliwości przeniesienia kapitału i pracy z innych gałęzi do wytwarzania większej podaży siły roboczej. Pod tym względem siła robocza różni się zasadniczo od innych towarów" (Lange 1975, 34).

42 Zagadnienie reprodukcji pracowników za pomocą pracy niezbędnej obejmuje cztery względnie niezależne aspekty: (i) kształtowanie się ceny siły roboczej, na którą mają wpływ siły popytu (potrzeby społeczne, styl życia) i podaży (postęp techniczny, wydajność) oraz prawo wartości (teoria płac opartych na wartości siły roboczej); (ii) kształtowanie się wartości siły roboczej, o którym rzeczywiście decyduje społecznie niezbędny czas pracy ucieleśniony w towarach wchodzących w skład koszyka towarów, jakie można nabyć za otrzymaną płacę; są to niezbędne środki utrzymania; (iii) produkcja siły roboczej za pomoca pracy niezbędnej; (iv) reprodukcja szczególnego kapitalistycznego stosunku produkcji siły roboczej (zob. Bowles i Gintis 1981, 8). 
Powzięta przez nas linię argumentacji potwierdza przywołany już wcześniej Sweezy, który stwierdza, że aby zachować wyjątkowy status pracy, należy zwrócić uwagę na podstawowy fakt, iż to nie tylko - jak chciał tego Marks - praca nie jest towarem, ale również „siła robocza” nie jest towarem. W związku z tym tradycyjna marksowska teoria wartości siły roboczej oparta na pracy abstrakcyjnej jest trudna do utrzymania. Powodem tego stanu rzeczy jest to, iż w warunkach kapitalizmu większa część produkcji najbardziej istotnego pojedynczego quasitowaru, siły roboczej, nie jest ani zorganizowana, ani kontrolowana przez kapitalistów. Ta kluczowa cecha wynika z faktu, którego przecież Marks nigdy nie stracił z oczu, mianowicie że istnieje jakościowa różnica między siłą roboczą a innymi towarami. Nie poszedł jednak tak daleko, aby stwierdzić, iż równie jakościowa różnica istnieje między rynkiem siły roboczej a rynkiem zwykłych towarów, gdyż to komplikowałoby mu przeprowadzenie dowodu o istnieniu wartości dodatkowej. Powstaje zatem problem, który jest zarzutem wymierzonym w tych, którzy - podobnie jak sraffianie - traktuja płacę roboczą jako określoną egzogenicznie. Problem ten polega na tym, że mechanizm dostosowujący stawkę płac i wartość siły roboczej jest zupełnie odmienny od tego, który rządzi dostosowaniem ceny każdego innego towaru do jego wartości. Przyczyną tej różnicy jest istnienie „rezerwowej armii bezrobotnych”, odgrywającej rolę platformy, na której dopiero odgrywa się działanie prawa popytu na pracę i podaży pracy (Sweezy 1981, 20).

Z tego fragmentu wynika, po pierwsze, że jeśli uznamy pracę za wartość użytkową dla kapitału, wówczas grozi to zredukowaniem społecznego procesu kapitalistycznej produkcji do technologicznie określonej „czarnej skrzynki”, a to nie byłoby zgodne z marksowskimi intencjami i faktem, że za wszelką cenę unikał on powoływania się na egzogeniczność różnych zmiennych. Po drugie, jeśli uznamy siłę roboczą za towar, wówczas musimy liczyć się z tym, że takie instytucje społeczne jak „szkoła” czy „rodzina” traktujemy jako „czarne skrzynki”, a to nie byłoby możliwe do utrzymania, biorąc pod uwagę ustalenia radykalnej ekonomii edukacji (Bowles i Gintis 1976) i ekonomii feministycznej (Folbre 1982, 317-329). Po trzecie, jeśli uznamy instytucję kapitalistycznej umowy o zatrudnienie pracownicze za kompletna, czyli precyzującą wszelkie istotne warunki, w jakich świadczona jest praca, wówczas albo milcząco redukujemy pracę do siły roboczej, albo zakładamy doskonałą zbieżność preferencji (interesów) pracownika i osoby zatrudniającej. Tę ostatnią kwestię również trudna zaakceptować $z$ uwagi na dobrze rozpoznaną niekompletność umów o pracę na kapitalistycznym rynku pracy. Zgodnie $z$ ta koncepcja świadczenie usług pracy stanowi transakcję ekonomiczną „dokonywaną w oparciu o umowę o zatrudnienie, która określa czas pracy, stawkę płacy oraz ogólny zakres obowiązków, przy czym, pozostaje ona w znacznej mierze niekompletna. Taka niekompletność przejawia się tym, że umowa nie precyzuje ex ante charakteru poszczególnych zadań, nie dostarcza ex ante zabezpieczeń gwarantujących wielkość 
faktycznej pracy oraz nie dostarcza ex ante kryteriów oceny staranności wykonania pracy" (K. Nowak 2011, 169, 184-186, 207-208).

Przypomnijmy, że na mocy poczynionego przez siebie założenia Marks próbował wyjaśnić wartość siły roboczej w kategoriach pracy abstrakcyjnej, traktując tym samym „szkołę” i „rodzinę” jako „czarne skrzynki”. Co więcej, w przypadku „siły roboczej” zastosował inne podejście niż w przypadku innych towarów, ponieważ rozpoczął swoje analizy nie od produkcji, lecz od konsumpcji siły roboczej. Postarajmy się prześledzić główne elementy jego argumentacji.

Dla Marksa punktem wyjścia jest rozróżnienie pracy, która sama w sobie nie ma wartości wymiennej, i siły roboczej (quasi-towaru), która ma swą cenę w postaci płacy roboczej (problem: czy płaca jest produkcyjna, czy nie jest?). Cena rynkowa siły roboczej oscyluje wokół wartości siły roboczej i w krótkich okresach może być od niej wyższa w zależności od wielkości podaży pracy i popytu na pracę oraz od „pierwiastków historycznych i moralnych”, ale nigdy nie spadnie poniżej jej poziomu, gdyż to zagroziłoby możliwości reprodukcji społecznej siły roboczej i podkopałoby możliwość osiagania zysku. Dlaczego tak się dzieje? Otóż dlatego, że wartość siły roboczej sama jest określana przez koszty produkcji (wytworzenia i odtworzenia) robotnika, a te koszty produkcji obejmują ilość (masę) środków utrzymania, koszty rozwoju siły roboczej oraz różnice naturalne (premie za uzdolnienia). Wszystkie te koszty razem wzięte wracaja do pracownika wskutek zatrudnienia i mają postać wartości wymiennej jego siły roboczej, czyli płacy roboczej: ani mniej, ani więcej. Co więcej, wartość siły roboczej jest określona także przez koszty reprodukcji społecznych stosunków produkcji, które nakazuja uczynienie z siły roboczej środka zatrudnienia. Widać zatem wyraźnie, że Marks antycypował Keynesa, ponieważ zakładał, iż to, co w ramach logiki kapitału wydaje się kosztem, w ramach logiki pracy jest dochodem (produkcyjna płacą robocza). Następnie pracownik realizuje całą płacę na reprodukcję własnej siły roboczej43. Gdzie tkwi błąd? Według Marksa reprodukcja siły roboczej odbywa się za pomoca pracy abstrakcyjnej, a ta - jak pamiętamy - występuje na rynku pod postacia odpłatnej pracy najemnej. Błąd polega nie tylko na pominięciu istotnej cechy siły roboczej, tj. jej częściowego wytwarzania poza systemem kapitalistycznym, ale także na tym, że dla Marksa punktem wyjścia jest tutaj logika konsumpcji, a nie produkcji. Marks nie dość wyraźnie odróżnia pracę abstrakcyjną od pracy społecznej. Skoro siła robocza nie jest towarem, a pracy nie sposób sprowadzić - w kontekście produkcji - wyłącznie do wartości użytecznej siły roboczej, to należy przeformułować teorię reprodukcji pracowników za pomocą pracy, odchodząc od klasycznej marksowskiej teorii wartości siły roboczej.

43 „Płace robocze - powiada J. Stuart Mill - nie mają siły produkcyjnej; są ceną siły produkcyjnej. Płace robocze nie wnoszą poza pracą samą do produkcji towarów nic, podobnie jak nie wnosi nic cena maszyny. Gdyby można było mieć pracę nie kupując jej, płace robocze byłyby zbyteczne" (Marks 1951, 647). Jak jednak komentuje Marks, „gdyby robotnicy mogli żyć powietrzem, to by ich nie można było kupić za żadną cenę” (Marks 1951, 647). 
Przypomnijmy, że zdaniem Marksa wartość siły roboczej można było koniec końców zredukować do nakładów najemnej pracy żywej, której ekwiwalentem ukrytym pod postacią płacy roboczej był koszyk środków utrzymania w formie towarów. Skoro - jak twierdził Marks - wszystkie towary były produktem pracy abstrakcyjnej, to tak samo miało być w przypadku osobliwego towaru, czyli siły roboczej. Stanowiła więc ona wytwór pracy abstrakcyjnej mierzonej w jednostkach społecznie niezbędnego czasu pracy. Każda indywidualna siła robocza wchodziła na rynek pracy, gdzie - po stawce płac odpowiadającej kosztom jej [re]produkcji - była spożytkowana w procesie „konsumpcji jej wartości użytkowej” przez kapitał w przedsiębiorstwie.

Niedopatrzenie Marksa polegało na tym, że kiedy mowa o sile roboczej, wówczas równie zasadne jest przyjęcie „logiki” i kontekstu produkcji. Oznacza to, że należy rozciagnąć proces produkcji i reprodukcji siły roboczej daleko poza obszar rządzony regułami logiki kapitalistycznej i otworzyć dwie „,czarne skrzynki”, szczelnie dotąd zamknięte dla marksowskiej teorii wartości. Wówczas należy raczej mówić o „pracy niezbędnej do wytworzenia siły roboczej”, a ta kategoria obejmuje sumę dwóch składników: (i) pracę abstrakcyjną, której alokacją rządzi rynek i która wytwarza towary (w tym „towarową” część siły roboczej) za pomocą nakładów odpłatnej, najemnej pracy żywej, wytwarzającej środki utrzymania w postaci artykułów konsumpcyjnych; (ii) pracę społeczna, której alokacją zawiaduje nie rynek, ale kultura (np. gender), państwo oraz tradycja i która wytwarza wartości użytkowe (w tym nieutowarowioną część siły roboczej) za pomoca nakładów nieodpłatnej pracy bezpośredniej (np. w gospodarstwie domowym) na różne sposoby niezbędnej do prawidłowego funkcjonowania społeczeństwa i jednostki oraz wnoszącej często niematerialny wkład do wartości użytkowej [i wymiennej? ${ }^{44}$ tej ostatniej. W takiej sytuacji koszt reprodukcji nie jest tylko i wyłącznie inną nazwą wartości siły roboczej, odkąd ten pierwszy rozrywa zakładany w ramach tej drugiej związek stawki płacy roboczej i kosztów produkcji siły roboczej. Odtąd, jak zauważają Samuel Bowles i Herbert Gintis, bardziej zasadne jest mówienie o wytwarzaniu siły roboczej i stosunków społecznych (rynkowych i pozarynkowych) ja reprodukujących za pomoca bezpośrednich i pośrednich nakładów pracy niezbędnej, niezbędnej do wytworzenia jednostki siły roboczej (Bowles i Gintis 1981). Wówczas siła robocza to nie produkt pracy abstrakcyjnej (towar), ale wytwór pracy niezbędnej, która również uwzględnia nakłady nieodpłatnej pracy społecznej.

44 Jeśli uznać za wiarygodne niektóre teorie i modele z obszaru współczesnej ekonomiki pracy (np. hipotezę o selekcji i sygnalizacji), głoszące, że „edukacja” (kształcenie) nie tyle podnosi wydajność (produktywność) i stąd płacę jednostki, ile stanowi narzędzie selekcji kandydatów pod względem zdolności i podatności na przyswajanie sobie wiedzy i szkoleń, to okazuje się, że rola „szkoły”, „praktyk zawodowych”, ,wychowania” nie sprowadza się tylko i wyłącznie do kształtowania wartości użytkowej, ale jest także zwiększaniem możliwości otrzymania większej płacy (Blaug 1987, 129-140). 
Wydaje się, że w przypadku teorii reprodukcji pracowników za pomoca pracy Marks w sposób zamierzony przedłożył towarowy charakter siły roboczej i „konsumpcyjny” kontekst pracy nad inne ich „podmiotowe” i ,produkcyjne” cechy i konteksty, z których przecież musiał zdawać sobie doskonale sprawę, a nawet wielokrotnie dawał temu wyraz. Jednak cel, jaki sobie postawił: wykazanie istnienia wartości dodatkowej i wyzysku, przysłonił mu inne możliwości. Poza wzięciem pod uwagę technicznych nakładów produkcji siły roboczej (środki utrzymania stanowiące ekwiwalent społecznie niezbędnego czasu pracy abstrakcyjnej) powinien również podkreślić w tym względzie rolę społecznych stosunków reprodukcji siły roboczej (stosunki społeczne uwzględniające pracę niezbędną w postaci pracy społecznej i nieodpłatnej pracy w gospodarstwie domowym). Tego rozróżnienia nie można pominąć, gdy rozpatruje się teorię wartości bezwzględnej mierzonej za pomoca pracy.

\section{Spór o status metodologiczny Marksowskiej wersji LTV}

Przywołane argumenty dają przybliżony obraz tego, jak wiele energii pochłonęła dyskusja na temat „pracy” i „,wartości” oraz ich znaczenia dla marksowskiej teorii wartości. Okazuje się, że nieproporcjonalnie dużo czasu poświęcono na rozwiązanie zagadki dotyczącej „problemu transformacji”, podczas gdy w dużym stopniu zaniedbano to, jaką teorią była w gruncie rzeczy propozycja Marksa? Pytania, jakiego typu teorią była wersja opracowana przez autora Kapitału, nie można oczywiście oddzielić od dwóch kwestii: sposobu rozumienia „wartości” i „pracy”, które składają się na podstawowe założenia teoretyczne propozycji Marksa, oraz od osobliwości stosowanej przez niego metody badawczej ${ }^{45}$.

System teoretyczny Marksa stanowił „sieć naczyń połączonych”, dlatego każda interpretacja marksowskiej krytyki ekonomii politycznej zawsze przysparzała i wciąż przysparza wiele problemów. Zresztą takie spostrzeżenie znajduja potwierdzenie w słowach samego Marksa, który twierdził, że już za jego życia „metoda zastosowana w Kapitale nie została dostatecznie zrozumiana, o czym świadcza już choćby jej różne i wzajemnie sobie przeczące pojmowania” (Marks 1951, 13). Dlatego wiele lat później Lukács przekonywał, że „ortodoksja w kwestiach marksizmu odnosi się raczej wyłącznie do metody" (Lukács 1988, 31). Odtąd to właśnie metoda miała stanowić differentia specifica ${ }^{46}$ marksowskiego podejścia, miała być tym, co odróżnia marksizm od innych stanowisk z zakresu nauk społecznych.

45 Więcej na temat osobliwości marksowskiej metody krytycznej zob. K. Nowak (2012, 101-116).

46 Najbardziej systematyczne na gruncie polskim studia metodologiczne nad statusem Marksowskiej wersji LTV, przede wszystkim nad „,prawem wartości” jako prawem idealizacyjnym, w którym Marks miał zastosować metodę „abstrakcji i stopniowej konkretyzacji”, przeprowadzili przedstawiciele tzw. Poznańskiej Szkoły Metodologicznej (zob. m.in.: Topolski et al. 1970; L. Nowak 1971). Podobnego wykładu metody Marksa z naciskiem na jej zastosowanie do ekonomii politycznej dostarczył w 1929 roku ekonomista polityczny Henryk Grossman w swojej książce Das Akkumulations - und Zusammenbruchsgesetz des kapitalistischen Systems 
Okazuje się, że sama metoda abstrakcji nie wytwarza wiedzy. Problem pojawia się wraz z jej zastosowaniem. Skoro jej zastosowanie wiąże się z poczynieniem co najmniej trzech metodologicznych sądów wartościujących w kwestii wyboru (i) tego, co jest przedmiotem badania, (ii) tego, co jest istotne, oraz (iii) tego, co dopuszcza się jako bazę opisowa, to istnieje niebezpieczeństwo odrzucenia ustaleń, które zostały wygenerowane na gruncie innych założeń niż założenia przyjęte przez krytyka. Rację ma Paul Sweezy, który stwierdził, że „znaczna ilość krytyk dotyczacych ekonomii Marksa, świadomie lub nieświadomie, opiera się na odrzucaniu przyjętych przez niego założeń. Nasze rozważania powinny przyczynić się do ustalenia kryteriów dla oceny słuszności tych krytyk. W każdym przypadku należy postawić następujące trzy pytania w sprawie upraszczających założeń (lub abstrakcji), które spotkały się z krytyką: 1) czy zostały ustalone pod kątem widzenia właściwym dla badanego zagadnienia?; 2) czy eliminuja nieistotne elementy zagadnienia?; 3) czy nie eliminują elementów istotnych? Jeżeli odpowiedź na te wszystkie trzy pytania wypadnie twierdząco, możemy powiedzieć, że zasada właściwej abstrakcji została zachowana. Zasada ta jest bardzo pomocna przy sprawdzaniu słuszności i wagi znacznej ilości argumentów wysuwanych przez krytyków Marksa" (Sweezy 1965, 35-36). Zarysowana przez Sweezy’ego zasada właściwej abstrakcji dotyczy sprawdzenia, czy koncepcja krytykująca nie pomija w swoich założeniach cech szczególnych koncepcji krytykowanej. Uwaga ta odnosi się zarówno do metody, jak i do pozostałych kwestii omawianych w niniejszym artykule, tj. do pojęcia wartości i pojęcia pracy.

Zależnie od sposobu podejścia do kwestii „,wartości” i „pracy” oraz metody badawczej komentatorzy marksowskiej wersji LTV różnie interpretowali jej status metodologiczny. Poniżej wskazane zostaną najistotniejsze, zdaniem autora, interpretacje statusu metodologicznego marksowskiej wersji LTV, które podkreślaja, że omawiana teoria ma charakter:

(i) idealizacyjny, który jest szczególnie widoczny w przypadku „prawa wartości” (Sweezy 1965; L. Nowak 1971) oraz w przypadku analizy stosunku treści zawartej w III tomie Kapitału do treści z I tomu Kapitału; tego typu interpretacja podkreśla stopnie przybliżenia, których dostarcza omawiana teoria (Dobb 1976, 160);

(ii) jakościowy (Fleetwood 2001, 41-77), który znajduje swój wyraz w teorii wartości bezwzględnej, podczas gdy charakter ilościowy dotyczy teorii wartości względnej; przy czym ta druga musi zakładać tę pierwszą ${ }^{47}$, nawet jeśli logicznie może wydawać się to niekonieczne ${ }^{48}$;

(Zugleich eine Krisentheorie). Ponadto swojego wykładu tej metody dokonał inny znakomity ekonomista Oskar Lange (1978).

47 Uwaga ta dotyczy również wielu innych teorii i modeli ekonomicznych z zakresu teorii popytu na pracę i modeli podaży pracy.

48 Wydaje się, że jedno ze źródeł wspomnianych kontrowersji dotyczy niejasnej struktury samej nazwy „teoria wartości opartej na pracy” i wywodzi się z faktu, że Marks nigdy - o ile piszącemu te słowa wiadomo nie użył tej nazwy w żadnym języku. Gdyby stało się inaczej, być może zaoszczędziłoby to niepotrzebnych 
(iii) nie-metafizyczny (Sen 1978, 175-183), który wyraża się w trzech interpretacjach:

- deskryptywnej, w ramach której opisywana jest działalność produktywna, a kryterium selekcji zogniskowane jest na osobistej partycypacji, co prowadzi do opisu procesu produkcji i wymiany w kategoriach stosunków między osobami; te stosunki powstają poprzez bezpośrednie uczestnictwo w procesie produkcji towarów, które dalej podlegają wymianie,

- predyktywnej, w ramach której na pierwszy plan wysuwa się możliwość stosowania „prawa wartości” do przewidywania kształtowania się cen, płac i zysków przy pomocy odpowiednich jednostek wartości,

- normatywnej, w ramach której na mocy metodologicznego sądu wartościującego osobiste uczestnictwo można uważać za podstawę nie tyle praktycznego uprawnienia do owoców bezpośredniej pracy, ile hipotetycznego roszczenia sobie prawa do wyłącznych korzyści z tytułu samego bezpośredniego wykonywania czynności nieuwzględnionych bądź niedookreślonych w umowie o zatrudnienie. Taka interpretacja opiera się na zasadzie, iż nasze sądy wartościujące mogą bazować m.in. na rzeczywistych założeniach, w taki sposób, iż fakt, jakie stwierdzenie opisowe dopuszcza się w ramach dociekań, może mieć bardzo znaczący wpływ na nasze kolejne sądy wartościujące (Nagel 1970, 415-430);

(iv) krytyczny, który wyraża się w interpretacji zainspirowanej uwaga poczynioną przez Marksa, że zastosowana przez niego metoda dociekań zakłada, iż „sposób wykładu musi różnić się formalnie od sposobu badania" (Marks 1951,15). W związku z tym należałoby wtedy mówić raczej o „krytycznej LTV” (analogicznie do „krytyki ekonomii politycznej”), w ramach której krytykę należy rozumieć jako formę dociekań raczej nieznaną reprezentantom klasycznej ekonomii politycznej. Ten właśnie fakt nie pozostawał bez wpływu na recepcję marksowskiej wersji LTV w środowisku ekonomistów niemarksistowskich. Jeśli uznać, że płodna poznawczo jest interpretacja, zgodnie z którą marksowskie ujęcie LTV można określić raczej jako krytykę (zob. K. Nowak 2012) klasycznej LTV, to w pierwszej kolejności należy zrekonstruować znaczenie, w jakim Marks stosował termin „krytyka”. Jeden z tropów prowadzi do interpretacji Marksowskiej „krytyki” w kategoriach objaśniających rozwój wiedzy naukowej. Zgodnie z nią Marksowska „krytyka” to swego rodzaju ekwiwalent Heglowskiego aufhebung czy też „korespondencji istotnie korygujaccej” Jerzego Kmity.

\footnotetext{
nieporozumień w kwestii tego, co rzeczywiście miał na myśli Marks: czy mówił o pracy w sensie przyczyny wartości wymiennej, a wówczas uzasadnioną ogólną nazwą byłyby „teoria wartości określanej przez pracę”, czy mówił o pracy w sensie miernika wartości bezwzględnej, i wtedy uzasadnioną ogólną nazwą byłaby „teoria wartości bezwzględnej mierzonej za pomocą pracy”, czy też mówił o pracy w sensie źródła wartości dodatkowej i wyzysku, co uzasadniałoby nazwę „,teoria wartości dodatkowej generowanej przez pracę”. Nigdy tak się jednak nie stało, tzn. Marks nigdzie explicite nie użył tego wyrażenia, co skazuje nas na dalsze bardziej lub mniej udane zmaganie $z$ tą zagadka.
} 


\section{Zakończenie}

Kwestia tego, co jest przedmiotem dociekań w ramach marksowskiej wersji LTV, wymaga odpowiedzi na pytanie, po co w ogóle teoria wartości (Blaug 2000, 246-247)? Jak autor tego tekstu starał się pokazać, nie jest to przecież wyłącznie teoria mająca wyjaśnić kształtowanie się cen względnych we współczesnym tego słowa znaczeniu. W jednej interpretacji ekonomicznej próbuje ona wyjaśnić podział dochodów między właścicieli kapitału i pracowników najemnych. W drugiej dąży się w jej ramach do sformułowania teorii wartości dodatkowej, przeciwstawiającej wartość siły roboczej wartości produktu końcowego. W jeszcze innej przedstawia się ją w kategoriach koncepcji etycznej, głoszącej „prawo pracy do całego produktu pracy”. Przywołane kontrowersje świadczą o tym, że trudno jest zupełnie zignorować nie tylko wnioski płynące z marksowskiej LTV, ale również sposób, w jaki do nich doszli badacze rozwijający tę koncepcję.

Benedetto Croce stwierdził kiedyś, że „system ekonomii, w którym pomija się wartość jest jak logika bez pojęcia, etyka bez powinności i estetyka bez ekspresji”" (Croce 1914, cyt. za: Dobb 1937, 3). W niniejszym artykule autor chciał zaznaczyć, że zepchnięcie „wartości” na peryferie badań ekonomicznych przyczyniło się do opisowego zubożenia teorii ekonomii, w wyniku czego utracono z pola widzenia istotny wymiar systemu gospodarczego w postaci „osobistej partycypacji” i stosunku do niej samego zaangażowanego podmiotu. Każdy przyczynek do rehabilitacji, czy też - jak stwierdziliby adwersarze - do reanimacji LTV (w wersji nie tylko zresztą marksowskiej), stanowi po części „reakcję na bezbarwną neutralność nowoczesnej ekonomii, rygorystycznie oddzielającej teorię cen od ekonomii dobrobytu” (Blaug $1995,248)$. 


\section{Wykaz literatury}

Ajdukiewicz, Kazimierz. 2006. Jezylk i poznanie. Tom II. Warszawa: Wydawnictwo Naukowe PWN.

Althusser, Louis. 1978. „The crisis of Marxism”. Marxism Today 22 (7): 215-221, 227.

Arendt, Hannah. 2000. Kondycja ludzka. Tłum. Anna Lagodzka. Warszawa: Fundacja Aletheia.

Arrow, Kenneth. 1962. „The economic implications of learning-by-doing.” The Review of Economic Studies 29 (3): 155-173.

Bellofiore, Riccardo. 2010. „Sraffa and Marx: a reopening of the debate.” http://host.uniroma3.it/eventi/sraffaconference2010/abstracts/pp_bellofiore.pdf.

Blaug, Mark. 1987. „Where are we now in the economics of education.” W The Economics of Education and The Education of Economists, red. Mark Blaug. Nowy Jork: New York University Press.

Blaug, Mark. 1995. Metodologia ekonomii. Tłum. Bogusław Czarny i Alina Molisak. Warszawa: Wydawnictwo Naukowe PWN.

Blaug, Mark. 2000. Teoria ekonomii. Ujecie retrospektynne. Tłum. Izabela Budzyńska i in. Warszawa: Wydawnictwo Naukowe PWN.

Bowles Samuel, i Herbert Gintis. 1981. „Structure and practice in the labor theory of value”. Review of Radical Political Economics 12 (4): 1-26.

Bowles, Samuel, i Herbert Gintis. 1976. Schooling in Capitalist America: Educational Reform and the Contradictions of Economic Life. New York: Basic Books.

Bowles, Samuel, i Herbert Gintis. 1977. „The Marxian theory of value and heterogeneous labour: a critique and reformulation". Cambridge Journal of Economics 1 (2): 173-192.

Bowles, Samuel, i Herbert Gintis. 1985. „The labor theory of value and the specificity of Marxian economics". W Rethinking Marxism: Essays for Harry Magdoff and Paul Sweezy, red. Stephen Resnick i Richards Wolff. Brooklyn: Autonomedia.

Bowles, Samuel. 1985. „Post-Marxian economics: labour, learning and history.” Social Science Information 24 (3): 507-528.

Bowles, Samuel, et al. 2005. Understanding Capitalism: Competition, Command and Change. Oxford: Oxford University Press.

Denison, Edward. 1961. „Measurement of labor input: some questions of definition and the adequacy of data". W Output, Input, and Productivity Measurement, The Conference on Research in Income and Wealth. http:/ / www.nber.org/chapters/c2230.pdf.

Dobb, Maurice. 1937. Political Economy and Capitalism. London: Routledge.

Dobb, Maurice. 1976. Teorie wartości i podziału od Adama Smitha. Tłum. Wiesława Raczkowska. Warszawa: Państwowe Wydawnictwo Ekonomiczne.

Duménil, Gérard. 1983-1984. „Beyond the transformation riddle: a labor theory of value.” Science and Society 47 (4): 427-450.

Fleetwood, Steve. 2001. „What kind of theory is Marx's labour theory of value? a critical realist inquiry." Capital and Class 73 (wiosna): 41-77.

Folbre, Nancy. 1982, „Exploitation comes home: a critique of the Marxian theory of family labor". Cambridge Journal of Economics 6 (4): 317-329.

Foley, Duncan. 2000. „Recent developments in the labor theory of value”. Review of Radical Political Economics 32 (1): 1-39.

Gintis, Herbert. 1972. „A radical analysis of welfare economics and individual development”. The Quarterly Journal of Economics 86 (4): 572-599.

Gordon, Donald. 1959. „What was the labor theory of value?” The American Economic Review 49 (2): 462-472. 
Habermas, Jürgen. 1983. „Między filozofią a nauką: marksizm jako krytyka.” Tłum.

Małgorzata Lukasiewicz, Zdzisław Krasnodębski. W Teoria i praktyka. Warszawa:

Państwowy Instytut Wydawniczy.

Habermas, Jürgen. 1987. „Odpowiedź na zarzuty.” W Wokół teorii krytycznej Jürgena Habermasa, red. Andrzej M. Kaniowski i Andrzej Szahaj. Warszawa: Warszawskie Centrum Studenckiego Ruchu Naukowego.

Habermas, Jürgen. 1999. Teoria driałania komunikacyjnego. Tom II. Tłum. Andrzej M. Kaniowski. Warszawa: Wydawnictwo Naukowe PWN.

Kołakowski, Leszek. 2000. Gtówne nurty marksiz̨mu. Cžść 1. Powstanie. Poznań: Zysk i S-ka.

Korsch, Karl. 1974. „The crisis of Marxism.” New German Critique 3: 7-11.

Lange, Oskar. 1975. „Ekonomia marksowska a współczesna teoria ekonomii”. W Drieła.

Tom III. Warszawa: Państwowe Wydawnictwo Naukowe.

Lange, Oskar. 1978. Ekonomia polityczna. Warszawa: Państwowe Wydawnictwo Naukowe.

Lukács, György. 1988. Historia i świadomość klasowa. Tłum. Marek Siemek. Warszawa: Państwowe Wydawnictwo Naukowe.

Mandel, Ernst. 1968. An Introduction to Marxist Economic Theory. London: Merlin Press.

Marks, Karol i Fryderyk Engels. 1949. Krytyka programu gotajskiego. W Diieła wybrane. Tom II. Warszawa: Książka i Wiedza.

Marks, Karol. 1951. Kapitat. Tom I. Warszawa: Książka i Wiedza.

Marks, Karol. 1953. Praycaynek do kerytykei ekonomï politycz̨nej. Tłum. Edward Lipiński. Warszawa: Książka i Wiedza.

Marks, Karol. 1986. Zarys krytyki ekonomii politycznej. Warszawa: Książka i Wiedza.

Meek, Ronald. 1958. Studia z. teorii wartości dodatkowej opartej na pracy. Tłum. Andrzej Leśniewski. Warszawa: Państwowe Wydawnictwo Naukowe.

Mirowski, Philip. 1989. More Heat than Light: Economics as Social Physics, Physics as Nature's Economics. Cambridge: Cambridge University Press.

Myrdal, Gunnar. 1953. The Political Element in The Development of Economic Theory. London: Routledge \& Kegan Paul LTD.

Nagel, Ernest. 1970. „Tendencja do wartościowań w badaniach społecznych”. W Nagel, Ernest, Struktura nauki. Tłum. Jerzy Giedymin, Bożydar Rassalski, Helena Eilstein. Warszawa: Państwowe Wydawnictwo Naukowe.

Napoleoni, Claudio. 1998. „The enigma of value.” International Journal of Political Economy 28 (3): $35-51$.

Nowak, Krzysztof. 2011. Status pojecia pracy w teorii ekonomii i teorii krytycznej. Poznań: Wydawnictwo Naukowe Instytutu Filozofii Uniwersytetu im. Adama Mickiewicza w Poznaniu.

Nowak, Krzysztof. 2012a. „Czym była Marksowska krytyka ekonomii politycznej?” Filozofia Publiczna i Edukacja Demokratyczna (1) 2: 101-116.

Nowak, Krzysztof. 2012b. „On ‘Capitalisation' of the concept of work in economic theory”. Studia Historiae Oeconomicae (30): 3-24.

Nowak, Leszek. 1971. U podstaw Marksowskiej metodologii nank. Warszawa: Państwowe Wydawnictwo Naukowe.

Parsons, Talcott. 1975. „Commentary on Herbert Gintis, A Radical Analysis of Welfare Economics and Individual Development". The Quarterly Journal of Economics 89 (2): 280-290.

„Producer and consumer sovereignty”. 2001. W Encyclopedia of Political Economy. Tom II, LZ, red. Phillip Anthony O'Hara. London: Routledge.

Robinson, Joan. 1953. „An open letter from a Keynesian to a Marxist.” W On Re-reading Marx. Cambridge: Students' Bookshops LTD. 
Robinson, Joan. 1960. „The labour theory of value”. W Collected Economic Papers. Tom II. Oxford: Basil Blackwell.

Robinson, Joan. 1960. Szkice o ekonomii marksistowskiej. Tłum. Helena Hagemejer. Warszawa: Państwowe Wydawnictwo Naukowe.

Robinson, Joan. 1974. Economic Philosophy. London: Penguin Books.

Samuelson, Paul. 1957. „Wages and interests: a modern dissection of Marxian economic models". The American Economic Review 47 (6): 884-912.

Schor, Juliet. 1998. „New economic critique of consumer society”. W Ethics of Consumption: The Good Life, Justice, and Global Stewardship, red. David A. Crocker, Toby Linden. Lanham: Rowman \& Littlefield Publishers.

Schultz, Theodore. 1962. „Reflection on investment in man”. The Journal of Political Economy 60 (2/5): $1-8$.

Sen, Amartya. 1978. „On the labour theory of value: some methodological issues”. Cambridge Journal of Economics 2 (2): 175-190.

Sen, Amartya. 1991. „Economic methodology: heterogeneity and relevance”. Methodus 3 (1): 67-80.

Shaikh, Anwar. 1998. „The empirical strength of the labor theory of value”. W Conference Proceedings of Marxian Economics: A Centenary Appraisal, red. Ricardo Bellofiore. London: Macmillan.

Steedman, Ian. 1977. Marx after Sraffa. Londyn: NLB.

Sweezy, Paul. 1965. Teoria rozwoju kapitalizmu. Tłum. Edward Lipiński. Warszawa: Państwowe Wydawnictwo Naukowe.

Sweezy, Paul. 1981. „Marxian value theory and crisis.” W Ian Steedman et al., The Value Controversy. London: Verso.

Szacki, Jerzy. 2004. Historia myśli socjologicznej. Warszawa: Wydawnictwo Naukowe PWN.

Topolski, Jerzy, i in. 1970. Założenia metodologiczne Kapitału Marksa, red. Barbara Janiec. Warszawa: Książka i Wiedza.

Tregenna, Fiona. 2009. The Specificity of Manufacturing in Marx's Economic Thought. http://www.dspace.cam.ac.uk/bitstream/1810/229493/2/0937.pdf.

Wolff, Richard, i Stephen Cullenberg. 1986. „Marxism and post-Marxism.” Social Text 15 (jesień): 126-135.

Wolfstetter, G. Elmar. 1973. „Surplus labour, synchronized labour costs and Marx’s labour theory of value". Economic Journal 83 (221): 787-809.

Ziembiński, Zygmunt. 2002. Logika praktyczna. Warszawa: Wydawnictwo Naukowe PWN. 
Krzysztof Nowak-Posadzy - jest filozofem ekonomii i adiunktem w Zakładzie Filozofii Kultury Instytutu Filozofii UAM. Od wielu lat zajmuje się problematyką rynku pracy, makroekonomii czy ekonomii stosowanej. Autor monografii Status pojecia pracy w teorii krytycznej i teorii ekonomii (2011) oraz współredaktor tomu Praxiology and the Reasons for Action (2015).

\section{DANE ADRESOWE:}

Instytut Filozofii Uniwersytetu im. Adama Mickiewicza w Poznaniu

ul. Szamarzewskiego 89C

60-568 Poznań

EMAIL: krzysztof.nowak@amu.edu.pl

CYTOWANIE: Nowak-Posadzy, Krzysztof. 2015. Jaką teorią jest Marksowska teoria wartości opartej na pracy?. „Praktyka Teoretyczna” 1(15): 15-56.

DOI: $10.14746 /$ prt.2015.1.1

\section{AUTHOR: Krzysztof Nowak-Posadzy}

TITLE: What kind of theory is the Marxian labour theory of value?

ABSTRACT: The so-called labour theory of value (LTV), once the pride of the whole Marxist political economy, over the years became the subject of its embarrassment. Its rejection within the leftist tradition, both by some philosophers as well as economists, is a part of a broader phenomenon called a "crisis of Marxism". In result, a philosophically oriented part of Marxist theory, trying to free Marxism from defects of "economism", also cutting it off from the benefits that may flow from the adoption of theoretical economics perspective. While some economic Marxists, in order to free the Marxist political economy from the shortcomings inherent in LTV also cut it off from the special status attributed to the notion of labour. Although later, LTV get acquitted from the charge of alleged logical contradiction, it was only in order to condemn it for oblivion for its alleged redundancy. In this article we will discuss the specifics of the Marxian version of LTV. The introduction gives four qualitative assumptions which, according to the author, determine the character of the Marxian version of the LTV. The first part outlines place that LTV holds in the history of economic thought. The second part focuses on the fate of the Marxian version of the LTV under the very Marxist tradition. 
The third part discusses the problem of value and its measurement. The fourth part is devoted to the analysis of the problem of labour and selection of the unit of its measurement, as well as tries to reconstruct Marx's theory of reproduction of employees through labour. The fifth part deals with the question of how to interpret a modern methodological status of the Marxian version of LTV. The article ends with a conclusion.

KEYWORDS: Marx, labour theory of value, value, political economy, Marxist political economy, measure, labour. 